ANDREW HYNES SERIES: TECTONIC PROCESSES

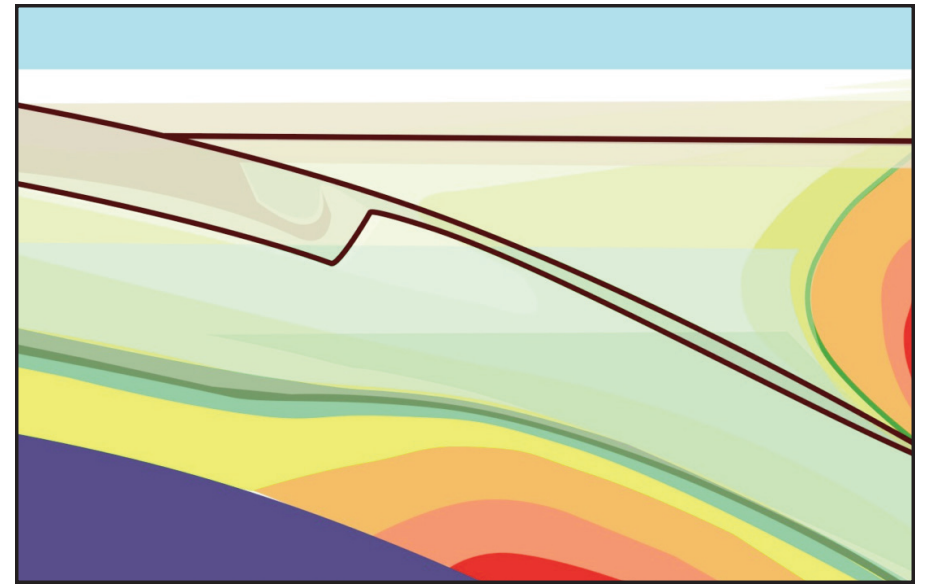

\section{Magmatism and Extension in the Foreland and Near-Trench Region of Collisional and Convergent Tectonic Systems}

\author{
Adam Schoonmaker ${ }^{1}$, William S.F. Kidd ${ }^{2}$ and \\ Tristan Ashcroft ${ }^{3}$
}

${ }^{1}$ Utica College, 1600 Burrstone Road,

Utica, New York, 13502, USA

E-mail:adschoon@utica.edu

${ }^{2}$ University at Albany, 1400 Washington Avenue,

Albany, New York, 12222, USA

${ }^{3}$ Ursinus College, 601 East Main Street,

Collegeville, Pennsylvania, 19426, USA

\section{SUMMARY}

Foreland magmatism occurs in the lower plate during arc-continent or continent-continent collision, although it is uncommon. Ancient examples are recognized by a stratigraphic section into which mafic lavas and/or shallow sills are emplaced at a level at the top of a passive margin cover sequence, or within the overlying deeper water deposits that include mudrocks and flysch-type turbidites. Extensional structures associated with the emplacement of the volcanic rocks may develop slightly prior to or contemporaneous with the arrival of the approaching thrust front. We have selected twelve examples of magmatism in collisional forelands, modern and ancient, and have compared the tectonic associations of the magmatism with the magmatic geochemistry.

Foreland magmatic settings fall into two strikingly distinct geochemical groups: a more enriched alkaline group (Rhinetype) and a more heterogeneous tholeiitic group (Maine-type) that may show traces of prior subduction processes. In the examples where the contemporaneous extensional structures are known, faults and basins develop parallel to the thrust front for the tholeiitic group and have oblique orientations, in several cases at a high angle to the thrust front, for the alkaline group. The geochemical results are quite sufficiently distinct to permit discrimination of these two foreland magmatic rock suites from each other in ancient examples where the foreland setting is clear from geological evidence. However, magmatic products of the same range of compositions can be generated in other tectonic environments (rifts, back-arc basins), so the geochemical characteristics alone are insufficient to identify a foreland basin setting.

The alkaline Rhine-type group formed primarily in response to localized upwelling convective activity from the sub-asthenospheric mantle beneath the lower plate during collision while the tholeiitic Maine-type group formed primarily in response to melting of subcontinental asthenospheric mantle during extension of the lower plate by slab pull, and resulting lithospheric detachment. It is possible that there has been a long-term secular decrease in the occurrence of the Mainetype foreland magmatism since the early Proterozoic.

\section{RÉSUMÉ}

Bien que peu fréquent, il arrive qu'un magmatisme d'avantpays se produise dans la plaque inférieure durant une collision arc-continent ou continent-continent. Des exemples anciens ont été décrits dans une coupe stratigraphique renfermant des laves mafiques et/ou des filons-couches au haut d'une séquence de couverture de marge passive, ou au sein de dépôts de plus grandes profondeurs comme des boues ou des turbidites de type flysch. Des structures d'étirement associées à la mise en place des roches volcaniques peuvent se développer un peu avant ou en même temps que l'arrivée du front de chevauchement. Nous avons choisi douze exemples de magmatisme au sein d'avant-pays de collision, modernes et anciens, et nous avons comparé les associations tectoniques du magmatisme avec la géochimie magmatique.

Les configurations magmatiques d'avant-pays se divisent en deux groupes géochimiques très différents : un groupe alcalin plus enrichi (type-Rhin), et un groupe tholéiitique plus 
hétérogène (type-Maine) et qui peut montrer des traces de précédentes activités de subduction. Dans les exemples où les structures d'étirement contemporaines sont connues, les failles et les bassins se développent parallèlement au front de chevauchement pour le groupe tholéiitique, alors que leurs orientations sont obliques, voire à angles aigus au front de chevauchement pour le groupe alcalin. Les résultats géochimiques sont suffisamment distincts pour permettre de distinguer ces deux suites de roches magmatiques dans les exemples anciens où la configuration d'avant-pays est évidente de par sa géologie. Cependant, des produits magmatiques de même type compositionnel peuvent advenir dans d'autres environnements tectoniques (fosses, bassins d'arrière-arc), et donc, la caractérisation géochimique seule ne permet pas de distinguer une configuration de bassin d'avant-pays.

Le groupe alcalin de type-Rhin s'est principalement formé en réponse à une activité d'éruption de convection issue du manteau sous-asthénosphérique sous la plaque inférieure durant la collision, alors que le groupe tholéiitique de typeMaine s'est formé principalement en réaction à la fusion du manteau sous-continental asthénosphérique durant l'extension de la plaque inférieure par étirement de la plaque, et le détachement lithosphérique qui en découle. Depuis le Protérozoïque, est possible qu'il y ait eu une décroissance progressive à long terme des événements magmatiques de type-Maine.

Traduit par le Traducteur

\section{INTRODUCTION}

Foreland magmatism that occurs in the outer trench slope of the lower plate during plate convergence is relatively uncommon. In several cases, this occurs when a continental margin enters the trench slope region and begins to interact with the upper plate, resulting in extension as the subducted oceanic lithosphere pulls on the continental margin lithosphere, and extensional failure and detachment of the attached oceanic lithosphere may occur. This model has been invoked for some occurrences; although a localized convective mantle upwelling can alternatively be used to explain magmatism in some foreland regions. We examine the following magmatic areas of Recent and/or Neogene age in the foreland setting: Rhine Graben (Germany), Karacadağ Volcanic Complex (SE Turkey), Penghu Islands (Taiwan), and 'Petit Spots' (outer Japan trench). In all of these areas the associated extension direction relative to the trench or thrust front is clear. We also examine ancient examples in old orogens of the Piscataquis Belt, Maine (Siluro-Devonian Acadian Orogeny); Starks Knob in New York, Jonestown Volcanics in Pennsylvania, and the Cortlandt Complex in New York, (Ordovician Taconic Orogeny); and the early Proterozoic Morel Sills and Ghost Dykes (Wopmay Orogen), and Molson Dykes and Flaherty Volcanics, (Circum-Ungava Orogen) from the Canadian craton (Table 1). We selected these examples because all are clearly associated spatially and temporally with an orogenic foreland setting, and because contemporaneous extensional structures and their regional orientation relative to the thrust front can be identified for most, and reasonably interpreted for the other (Flaherty Formation) of these occurrences.
This paper briefly describes the geological setting of these twelve modern and ancient examples of foreland magmatism and then examines the geochemical compositions of each, seen in the context of the two geological groups that can be defined from the associated extension direction relative to the trench or thrust front.

\section{BACKGROUND}

Foredeep magmatism was first described by Hoffman (1987) as magmatic activity occurring in continental margin stratigraphy immediately preceding, or during the onset of flysch deposition and deformation resulting from active arc--continent collision. Concurrent foreland basin deposition occurs and overlies passive margin stratigraphic sequences. Flexure occurs in the lower plate as it enters the outer trench slope region of a subduction zone and the continental margin begins to interact with the upper plate during collision (Fig. 1). The slab-pull force caused by sinking of the last subducting oceanic lithosphere (and/or some of the continental mantle lithosphere if it delaminates from the crust) may cause extension of the lithosphere, including the continental part (Schoonmaker et al. 2005) allowing mantle upwelling and magmatism into the lower plate. This process may progress to breakoff of the subducted or delaminated slab, which might trigger, or enhance, the magmatism (e.g. Davies and von Blanckenburg 1995; Cloos et al. 2005). We expand Hoffman's (1987) original description of foreland magmatism to include magmatism occurring in the foreland of a continent in the process of colliding either with an arc or with an upper plate continent, and contemporary magmatism emplaced in the toe of the overriding accretionary complex.

An alternative process was identified by Şengör et al. (1978) for extensional tectonism and associated magmatism in an active orogenic foreland, caused by the regional stress field propagating into the foreland lithosphere from a collisional orogen, with consequent extension perpendicular to the maximum compressive stress orientation. The Cenozoic Rhine Graben situated adjacent to the Western Alps provided the type example for Şengör et al. (1978), and illustrates the localized nature of these features.

These processes have been proposed to explain foreland magmatism in young examples such as the Rhine Basin (Bogaard and Wörner 2003; Jung et al. 2005; Lustrino and Carminati 2007), Karacadağ Volcanic Complex, Eastern Anatolia (Pearce et al. 1990; Keskin 2003; Sengör et al. 2003; Ekici et al. 2012), Penghu Islands, Taiwan (Chung et al. 1994; Wang et al. 2012), 'petit spot' volcanoes of the Pacific plate near the Japan Trench (Hirano 2011) and ancient analogue examples such as the Piscataquis Volcanic Belt, Maine (Schoonmaker et al. 2011) and Starks Knob, New York (Landing et al. 2003), and the Precambrian examples identified by Hoffman (1987).

Alternatively, mantle plumes have been suggested to explain magmatism in the Rhine Basin (Ritter et al. 2001; Keyser et al. 2002; Haase et al. 2004) and Eastern Anatolia (Ershov and Nikishin 2004), but not the other young examples listed here. For the older examples, large igneous province (LIP) plume-head association has been suggested for the 
Table 1. Summary of sources of geochemical analyses used for this study.

\begin{tabular}{|c|c|c|c|c|}
\hline Location & Formation & Age & \# of Analyses & Source \\
\hline Rhine Graben & $\begin{array}{l}\text { Rockeskyllerkopf } \\
\text { Vogelsberg } \\
\text { Rhön } \\
\text { Hocheifel }\end{array}$ & $\begin{array}{l}\text { Quaternary } \\
\text { Miocene } \\
26-11 \mathrm{Ma} \\
44-34 \mathrm{Ma}\end{array}$ & $\begin{array}{c}53 \\
71 \\
7 \\
35\end{array}$ & $\begin{array}{l}\text { Shaw and Woodland } 2012 \\
\text { Bogaard and Wörner } 2003 \\
\text { Jung et al. } 2013 \\
\text { Jung et al. } 2006\end{array}$ \\
\hline East Anatolia & $\begin{array}{l}\text { Karacadağ } \\
\text { (Siverek phase) }\end{array}$ & Neogene & 27 & Ekici et al. 2012 \\
\hline \multirow[t]{2}{*}{ Taconic foreland } & $\begin{array}{l}\text { Cortlandt Complex } \\
\text { Starks Knob }\end{array}$ & $\begin{array}{l}446 \pm 2 \mathrm{Ma} \\
\text { Upper Ordovician } \\
\text { (Trenton) }\end{array}$ & $\begin{array}{l}9 \\
9\end{array}$ & $\begin{array}{l}\text { Bender } 1980 \\
\text { Landing et al. } 2003\end{array}$ \\
\hline & Jonestown & Middle Ordovician & 25 & $\begin{array}{l}\text { Lash 1986; Smith and Barnes } \\
\text { 1994; Ashcroft } 2002\end{array}$ \\
\hline Taiwan & Penghu basalt & Miocene & 12 & $\begin{array}{l}\text { Chung et al. 1995; Wang et } \\
\text { al. } 2012\end{array}$ \\
\hline Japan outer trench slope & Petit spots & $8.5-0.5 \mathrm{Ma}$ & 7 & Hirano et al. 2006 \\
\hline $\begin{array}{l}\text { Baffin Island } \\
\text { (Rae craton) }\end{array}$ & Bravo Formation & $1923 \pm 15 \mathrm{Ma}$ & 9 & Partin et al. 2014 \\
\hline Maine Acadian & West Branch Volcanics & Late Silurian & 12 & $\begin{array}{l}\text { Fitzgerald 1991; } \\
\text { Schoonmaker et al. } 2005\end{array}$ \\
\hline Wopmay Foreland & $\begin{array}{l}\text { Morel Sills } \\
\text { Ghost Dykes }\end{array}$ & $\begin{array}{l}\text { ca. } 1.88 \mathrm{Ga} \\
\text { ca. } 1.88 \mathrm{Ga}\end{array}$ & $\begin{array}{l}6 \\
9\end{array}$ & $\begin{array}{l}\text { Minifie } 2010 \\
\text { Minifie } 2010\end{array}$ \\
\hline NW Superior Province & Molson Dykes & ca. $1.88 \mathrm{Ga}$ & 33 & $\begin{array}{l}\text { Heaman et al. 2009; } \\
\text { Minifie } 2010\end{array}$ \\
\hline Belcher Islands & Flaherty Formation & $1960 \pm 80 \mathrm{Ma}$ & 7 & Legault et al. 1994 \\
\hline
\end{tabular}

Canadian Proterozoic examples marginal to the Slave and Superior cratons (Minifie 2010).

\section{FORELAND SETTINGS}

We divided the examples discussed below into two groups (Rhine-type vs. Maine-type), based on the regional orientation of the associated extensional structures. In this section we review the evidence for a foreland interpretation and the extensional stress orientation associated with each. Rhine-type foreland magmatism is associated with extensional structural orientations that are oblique to, and in several cases at a high angle to, the adjacent thrust front or trench; Maine-type foreland magmatism is associated with extensional structures oriented parallel to the adjacent thrust front (Fig. 2). Some of the settings described here are modern or recent where the foreland position of magmatism and structural orientation is clear, but for the ancient examples their interpretation as foreland basin magmatism critically depends on the stratigraphic relationship between the volcanic units and continental passive margin sedimentary strata and foreland basin clastic rocks (fly- sch), as well as to subsequent shortening deformation. In the discussion, two additional examples where clear structural data regarding extensional structure orientation are lacking are reviewed briefly, and a predicted assignment made to one of the groups based on their geochemical compositions. The essential properties of the two groups are summarized in Table 1 and discussed in more detail below.

\section{Rhine-Type Foreland Magmatism and Extensional Structures}

Modern or recent examples of Rhine-type foreland magmatism include the eponym Rhine Graben (Germany), Karacadağ Volcanic Complex (SE Turkey), Penghu Islands (Taiwan), and the 'Petit Spots' volcanoes of the Pacific seafloor, east of the Japan Trench; we identify one ancient example, the Cortlandt Complex-Beemerville zone (New York). The geochemical character of the Piling Group in the Proterozoic Trans-Hudson Orogen of Canada suggests that it belongs to this group (see discussion). 


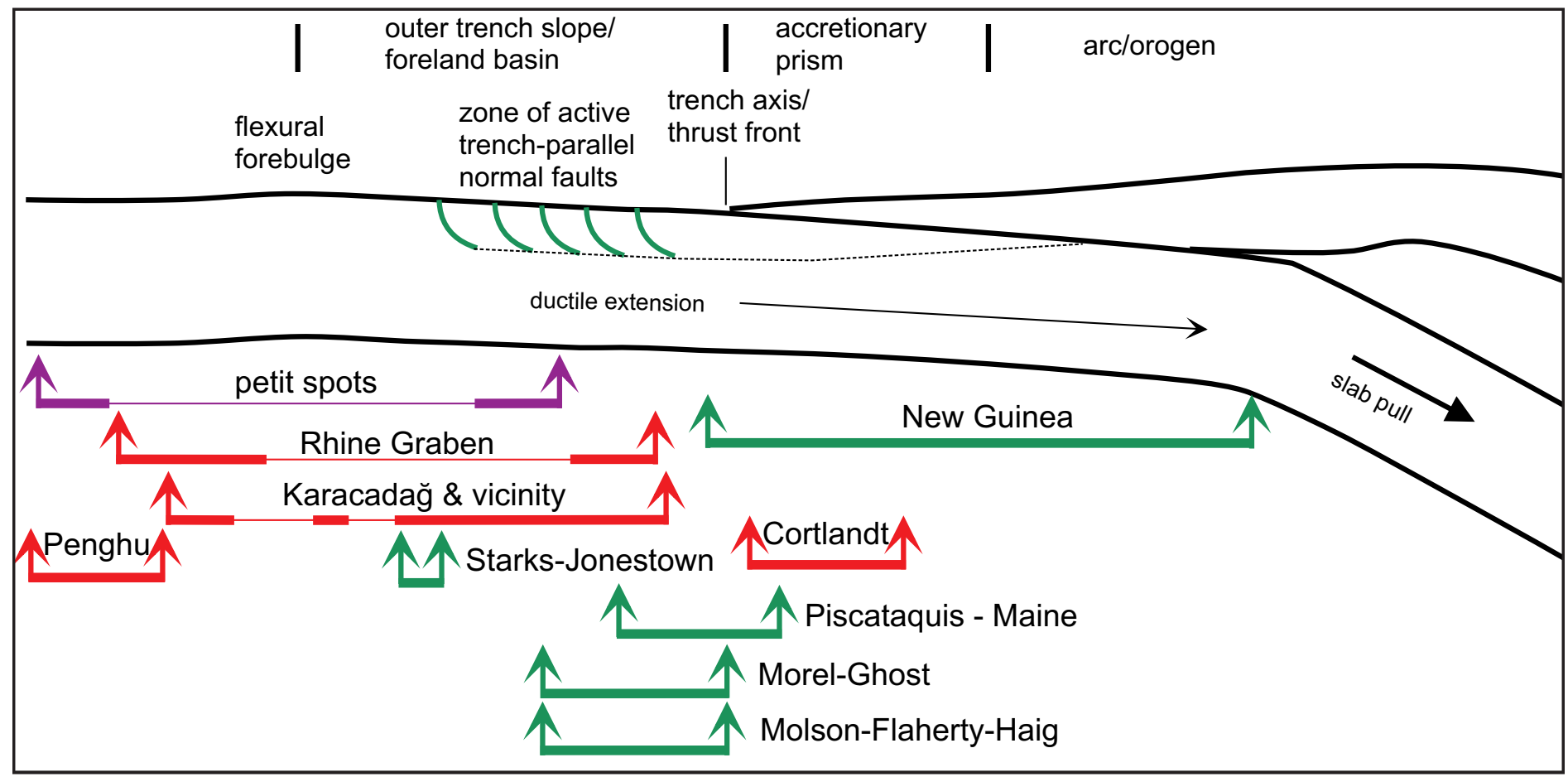

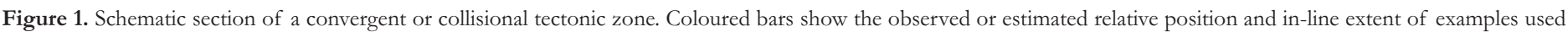

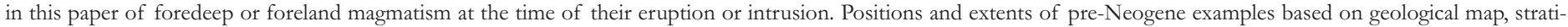

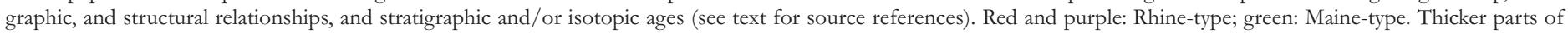
lines are locations of magmatism. Purple line is for magmatism on oceanic lithosphere; red and green on continental lithosphere.

\section{Rhine Graben (Germany)}

Within the European Cenozoic Rift System, the Upper and Lower Rhine basins are associated with significant volcanism of the Central European Volcanic Province (Fig. 3). The longitudinal axes of the Rhine Graben are either oblique (Lower Rhine Basin) or nearly perpendicular (Upper Rhine Basin) to the northern thrust front of the adjacent Alps and the Insubric Line suture to the south. Sengör et al. (1978) were the first to link the main Rhine Graben as a rift structure to the compressional stress orientation induced in the orogenic foreland by the Alpine collision, and to use it as the type example of such structures. The Lower Rhine basin displays evidence for sinistral transtension (Cardozo and Behrmann 2006) but there are numerous normal faults along which significant NE-SW extension has occurred, and earthquake focal mechanisms indicate the current stress field is similarly oriented (Homuth et al. 2014).

\section{Karacadağ Volcanic Complex (SE Turkey)}

Karacadağ is a large basaltic shield volcano located in the northernmost Arabian foreland (Fig. 4), where there has been volcanism since the mid-Miocene, although the shield volcano is Pliocene and younger (Ekici et al. 2012, 2014). The longitudinal crest and main fissure eruption source of Mount Karacadağ is oriented close to $\mathrm{N}-\mathrm{S}$, nearly perpendicular to the Bitlis suture and the nearby thrust front of the foreland basin in which this magmatism occurs (Şengör and Kidd 1979; Pearce et al. 1990). Furthermore, the N-S oriented Neogene Ackakale Graben located to the southwest suggests the same
E-W extension direction. Yürür and Chorowicz (1998) measured structural data in a nearby area (Amanos Range) that indicate a change from N-S contraction to ENE-WSW extension for the most recent fault motions. Ekici et al. (2012) reported eruption of some of the earlier Miocene plateau basalt from fissures on the northern side of the area that are oriented parallel to the nearby thrust front.

\section{Penghu Islands (Taiwan)}

The Penghu Islands in the strait west of Taiwan, composed of a series of mafic volcanic flows and shallow sills on the eastern China continental margin (Fig 5), were pointed out by Hoffman (1987) as a likely example of foreland magmatism, based on the age then provided for the volcanic rocks as early Pleistocene or Pliocene. Subsequent work reported consistent $\mathrm{K}-$ Ar ages for the volcanics of mid-late Miocene age (16-8 Ma; Juang and Chen 1992; Wang et al. 2012), along with upper middle Miocene marine microfossil ages from interbedded sedimentary layers. Paleostress orientations determined from fracture sets in the volcanics (Angelier et al. 1990) give extensional stress orientations nearly parallel with the current Taiwan thrust front for structures in 16-11 Ma volcanics, and oblique to that thrust front for those in 9-8 Ma volcanics, although the latter orientation is parallel with the present PhilippineYangtze-Eurasia plate convergence direction across the Manila Trench (shown and referenced on Fig. 5). Dominantly trenchfacing $\sim$ NNE-striking normal faults, mostly with small displacements and which cut Pliocene and early Pleistocene foredeep strata, have been mapped in the Taiwan Strait up to about 


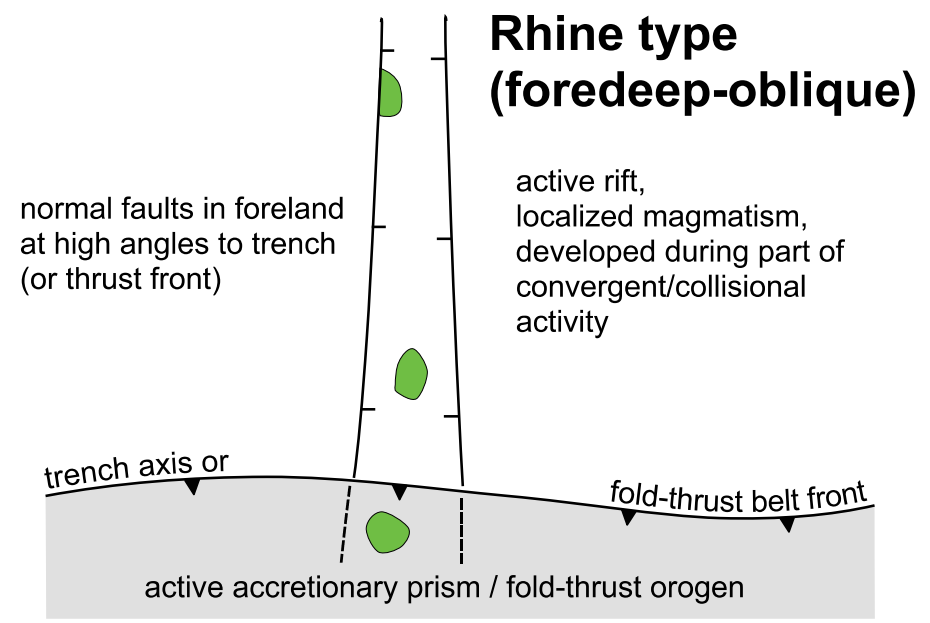

Maine type (foredeep-parallel)

magmatism in outer slope of active foredeep or/and in accretionary toe

normal faults trench-parallel flexural bulge axis mostly trench-facing

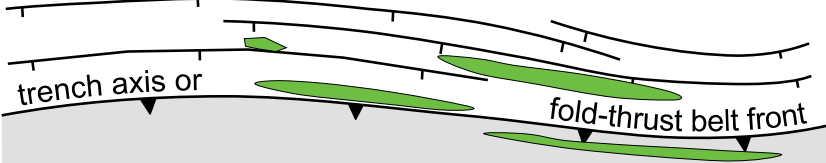

active accretionary prism / fold-thrust orogen

Figure 2. Schematic map-view location and orientation of normal faults and magmatism for Rhine-type compared with Maine-type foreland basins, and their adjacent fold or thrust belts. Normal faults are shown by conventional tick mark symbols on down-thrown sides; green: areas of concurrent magmatism.

$100 \mathrm{~km}$ west of the active thrust front in Taiwan (Chou and $\mathrm{Yu}$ 2002), but no volcanism of this younger age range is known in this area.

\section{'Petit Spots' (NW Pacific Seafloor Adjacent to Japan Trench)}

The 'petit spots' are a series of young (ca. 8-0 Ma), small alkaline volcanoes on the Pacific sea floor, east of the Japan Trench (Hirano et al. 2006; Hirano 2011; Fig. 6). The younger ones (estimated by Hirano to be no older than $1 \mathrm{Ma}$ ) are in two areas, one (1 on Fig. 6) located on the upper part of the outer trench slope, but the other ( 2 on Fig. 6) is about $400 \mathrm{~km}$ from the trench. The older volcanic rocks (dated as ca. 8-4 Ma) are in the third small group, (3 on Fig. 6) now found close to the trench floor, but which must have been far behind the position of the flexural bulge crest at the time of eruption. Some of the petit spots in the older area (3) form linear chains oriented WNW-ESE (Hirano et al. 2006). The envelope of the area of most of the occurrences in the young group (1) near the trench, and of all the older group (3), are elongated at a high

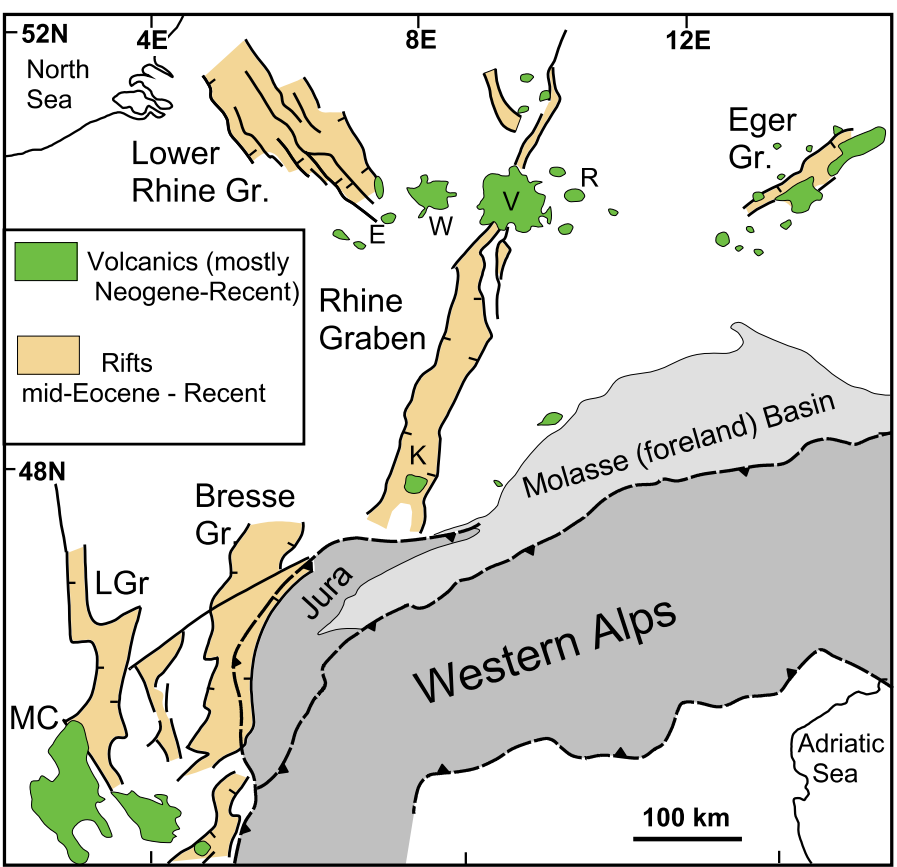

Figure 3. Location of the Rhine Graben and other parts of the European Cenozoic Rift System and magmatism of the Central European Volcanic Province in relation to the western Alps and its northern foreland basin. Map modified from Dèzes et al. (2004). E - Eifel, K - Kaiserstuhl, LGr - Limagne Graben, MC - Massif Central, R - Rhon, W - Westerwald, V - Vogelsburg.

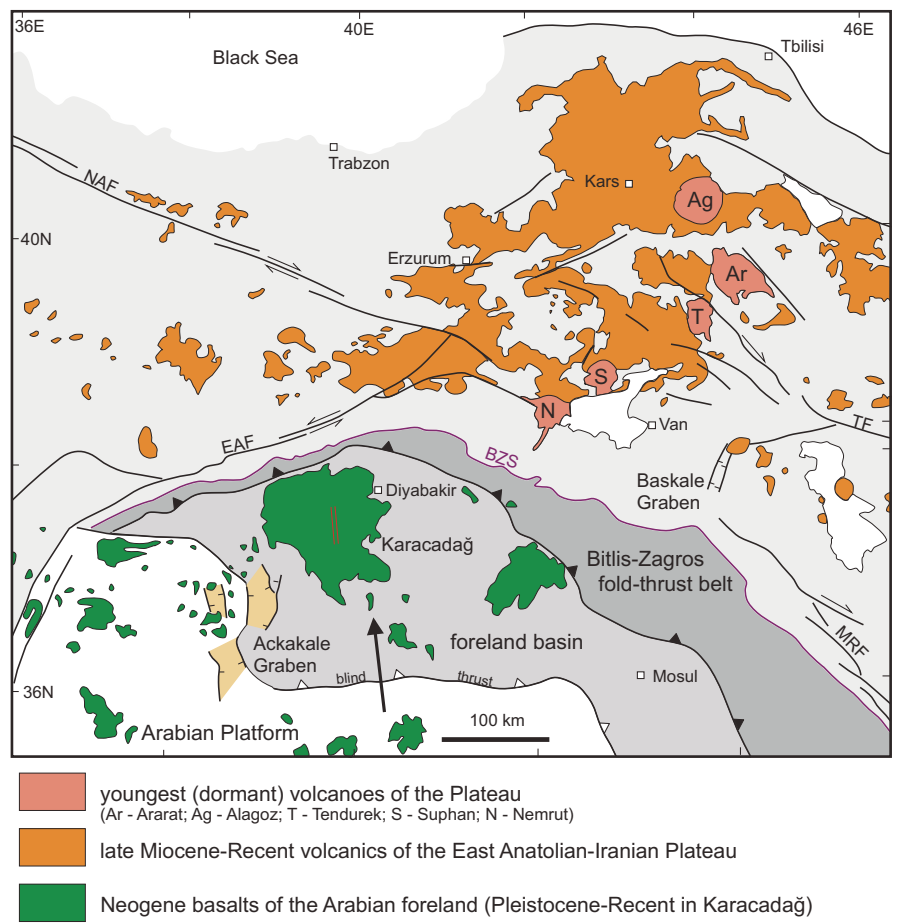

Figure 4. Volcanic rocks of the Eastern Anatolian-Iranian Plateau and adjacent northern Arabian foreland. Red parallel lines in Karacadağ are the summit ridge and eruptive fissure alignment. NAF - North Anatolian Fault, EAF - East Anatolian Fault, BZS - Bitlis-Zagros Suture, TF - Tabriz Fault, MRF - Main Recent Fault. Map modified from Pearce et al. (1990). Black line with arrowhead is direction of Arabian-Eurasian plate motion for 3-0 Ma from MORVEL data (DeMets et al. 2010). 


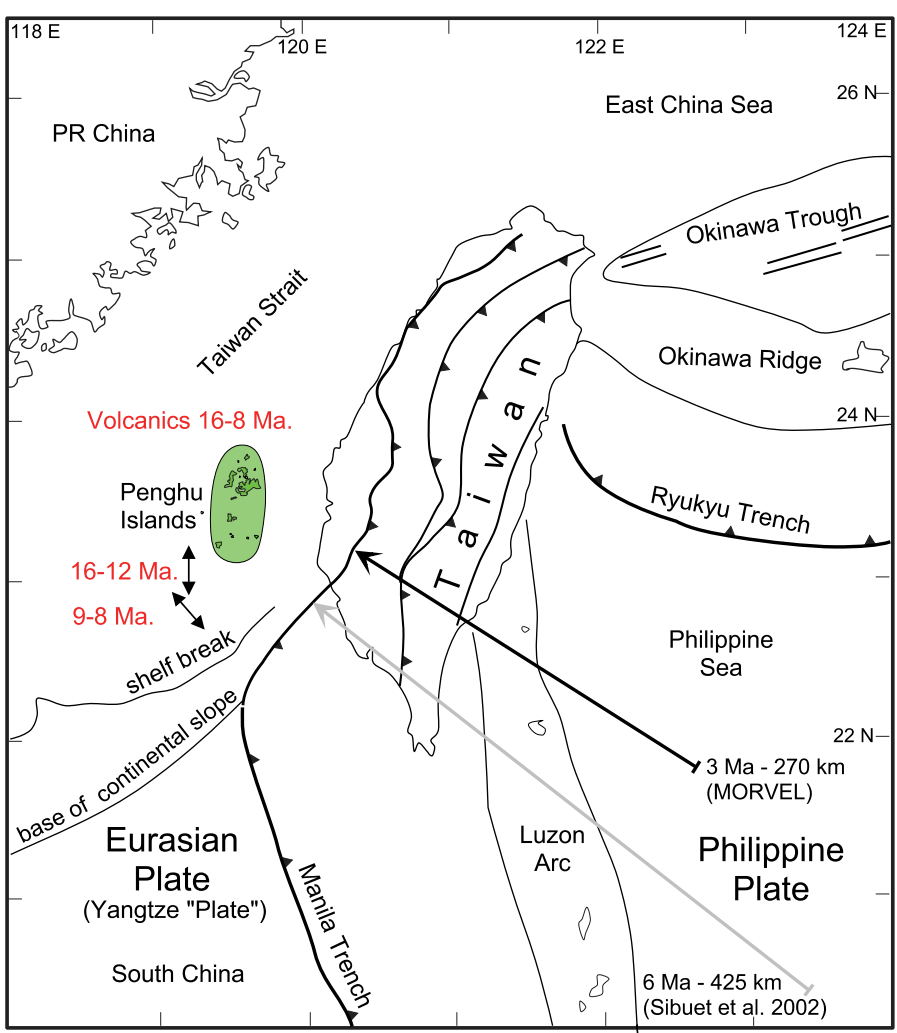

Figure 5. Setting of the Penghu Islands in the Taiwan-East China margin collision. Volcanic age range in Penghu Islands from Juang and Chen (1992). Paleostress extension orientations in Penghu volcanic rocks from Angelier et al. (1990) shown by short double-headed arrows. Map modified from Angelier et al. (1990) and Huang et al. (2006). Single-headed black line with arrow is Philippine-Yangtze plate convergence direction from MORVEL data (DeMets et al. 2010); length of line 270 $\mathrm{km}$ for 3 M.y. convergence (rate $90 \mathrm{~mm} / \mathrm{a}$ ). Single-headed grey line with arrow is Philippine-Eurasia plate convergence direction for 8 to $0 \mathrm{Ma}$, from Sibuet et al. (2002); length of line $425 \mathrm{~km}$ for the past 6 M.y. convergence (rate $71 \mathrm{~mm} / \mathrm{a}$ ).

angle to the trench in a similar orientation (Fig. 6), which is also the direction of the NUVEL-1A plate motion vector. Bathymetry and acoustic reflectivity show well-developed trench-parallel normal faulting on the outer trench slope of the Japan and Kurile trenches (Kobayashi et al. 1998). Some of the younger group 1 volcanoes occur within this zone, but their locations show no clear evidence of being controlled by this extension, and those of group 3 are older than and cut by these faults (Hirano 2011). In none of the groups do they appear to be influenced by the old sea floor spreading fabric. While one occurrence (2) is near a large fracture zone, the individual spots in it do not show alignment in chains of this fracture zone orientation, or any other. We think the obliquely oriented overall distribution of these volcanic occurrences, including the younger ones on the outer trench slope, suggest that they belong in the Rhine-type category.

\section{Cortlandt Complex-Beemerville Magmatic Zone (Taconic of New York)}

The Cortlandt Complex (ca. $446 \mathrm{Ma}$ ) and related zone of dykes leading west to the Beemerville intrusion (Fig. 7) are part of a series of alkaline intrusions forming a zone that cuts at a high angle across the regional Taconic foreland thrust fabric

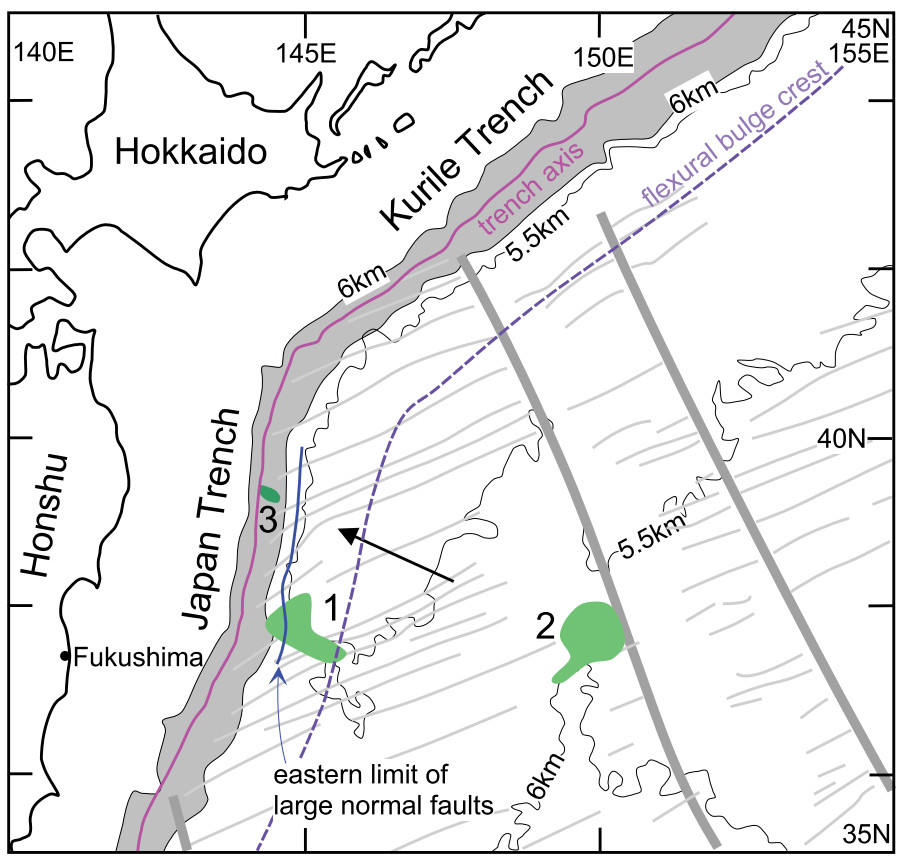

Figure 6. Map of the occurrence of 'petit-spot' volcanism east of the Japan Trench (modified from Hirano et al. (2006), Hirano (2011). Bright green areas $(1,2)$ are volcanic rocks younger than ca. $1 \mathrm{Ma}$; small darker green area (3) contains volcanic rocks ca. 8-4 Ma old. Black arrow is NUVEL-1A plate convergence direction. Thin grey lines - Cretaceous spreading magnetic anomalies, thick grey lines - fracture zones, grey shading - Japan Trench below $6 \mathrm{~km}$ bathymetric contour.

(Bender 1980; Ratcliffe 1981; Domenick and Basu 1982; Bender et al. 1984; Ratcliffe et al. 2012). Dykes within this zone and its overall trend indicate extension approximately NNWSSE, somewhat oblique, but not at a high angle to the surrounding strike of the Taconic thrust assemblage. This magmatic event and the extensional structures evidenced by the dykes occurred late in the Taconic collisional event (Ratcliffe et al. 2012). It is not known if this zone extends farther west into the Taconic foreland under Silurian and younger cover. In orientation, orogenic timing and geochemistry, this ancient example resembles the younger part of the development of the Rhine Graben.

\section{Maine-Type Foreland Magmatism}

We have not identified modern examples of Maine-type foreland magmatism where the magmatism is mostly localized in or immediately below the foreland basin strata, and where the magmatism is dominantly of the Maine-type compositional range. Ancient examples included in this paper are the Piscataquis Volcanic Belt of Maine, Starks Knob and the Jonestown Volcanics of the Taconic Foreland (New York and Pennsylvania, respectively), and the Morel Sills, Ghost Dykes, and Flaherty Volcanics-Haig Sills in the Proterozoic of Canada.

\section{Piscataquis Volcanic Belt (Maine)}

The Piscataquis Volcanic Belt, largely exposed in Maine, but extending into New Brunswick and New Hampshire, is latest Silurian-early Devonian in age. Its geographic extent roughly parallels the orogenic fabric of the Acadian Orogeny in this 


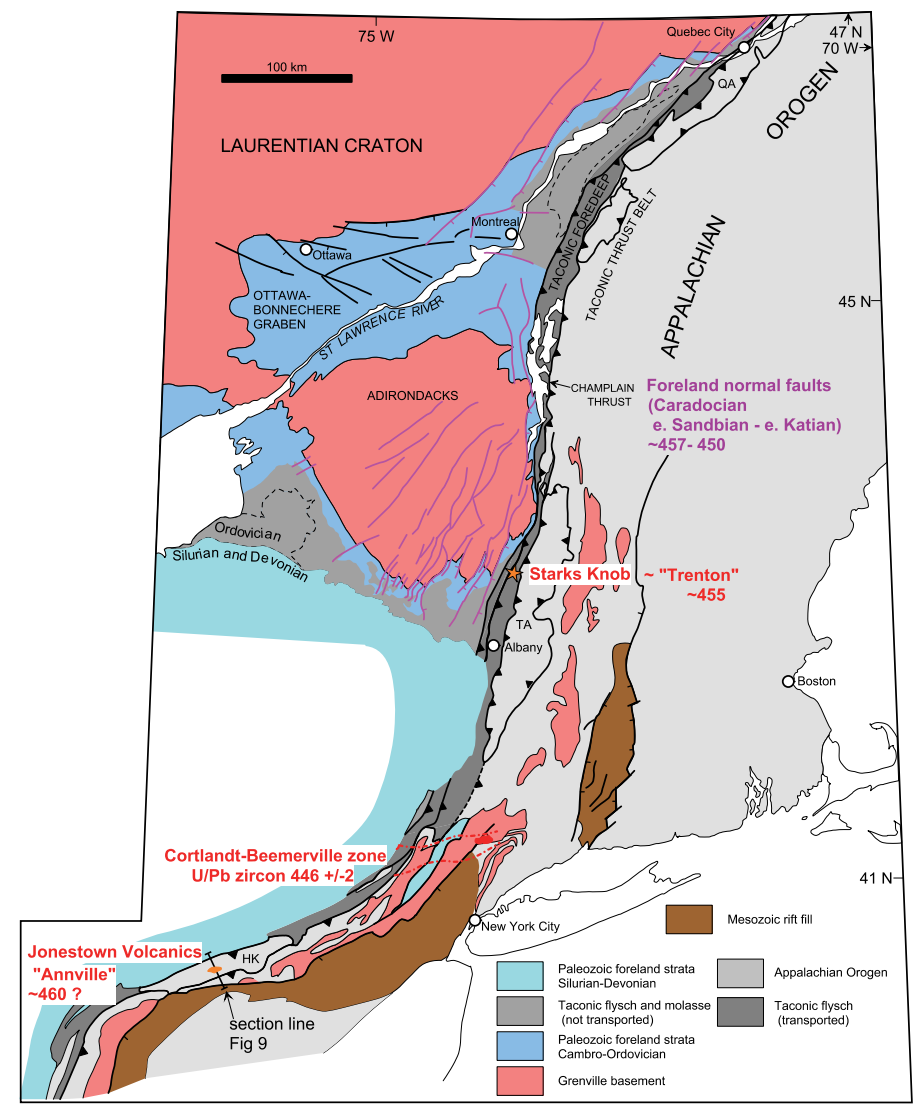

Figure 7. Overview map of the Taconic Laurentian foreland of the northeastern US and adjacent part of Canada, showing the locations of Starks Knob, the Cortlandt-Beemerville magmatic zone, the Jonestown Volcanics, and the Ordovician foreland normal fault system. Taconic allochthons: HK - Hamburg Klippe, QA Quebec Allochthon, TA - Taconic Allochthon.

area (Fig. 8). Its petrogenesis has been debated and further information is contained in these references: van Staal et al. (1998, 2009); Eusden et al. (2000); Bradley and Tucker (2002); Murphy and Keppie (2005); and Schoonmaker et al. (2005, 2011). Syn-sedimentary normal faults, which are oriented parallel with slightly younger Acadian thrust fabrics nearby, occur in sedimentary strata just below the volcanic rocks (Schoonmaker et al. 2005; Schoonmaker and Kidd 2013). The dyke-like Moxie Pluton, a major gabbroic body dated at ca. $406 \mathrm{Ma}$ (Bradley et al. 2000), which cuts some of the Acadian thrust fabrics in foreland basin sedimentary rocks, has a similar strikeparallel orientation. The volcanics are within marine strata, and some show pillowed form. Locally subaerial eruption may have occurred (Boucot et al. 1964), but a well-exposed section near the west margin of the Katahdin Pluton (Fig. 8) contains all these volcanics in deeper water clastic rocks deposited just above the Silurian-earliest Devonian shallow marine shelf strata (Schoonmaker et al. 2011).

\section{Starks Knob (New York)}

Starks Knob is a small remnant block of pillow lavas interpreted to have been erupted into the outer part of the Laurentian passive margin just before the arrival and collision of the Taconic accretionary thrust complex (Landing et al. 2003).

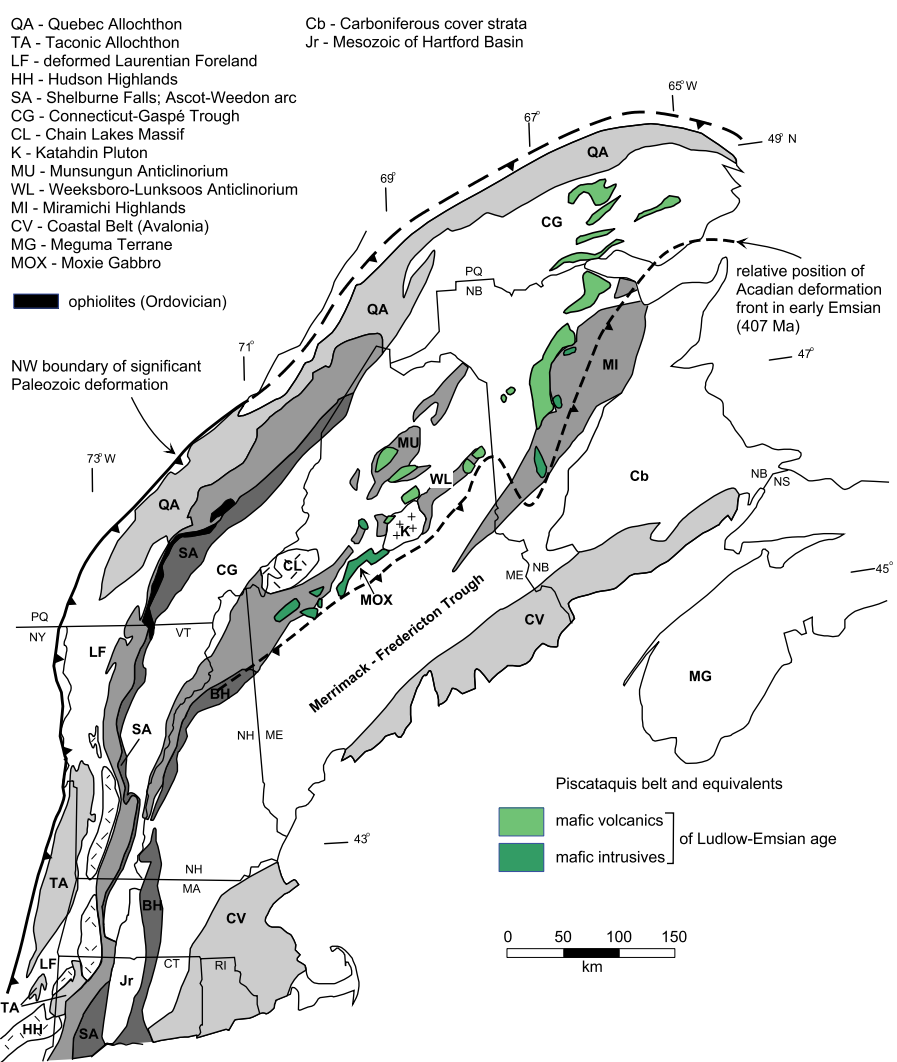

Figure 8. Map of regional elements of the mainland Northern Appalachians showing the setting of the Piscataquis magmatic belt. Adapted from Schoonmaker et al. (2011). Position of the early Emsian Acadian deformation front across Maine is from Bradley et al. (2000), speculatively extrapolated farther NE.

This block was tectonically transported to its present position within the mélange of that accretionary complex (Fig. 7), now lying above the Laurentian foreland of New York State (Landing et al. 2003). The volcanic rocks contain only interstitial limestone, indicating shallow marine eruption; the regional clast association in the mélange is only with the Laurentian passive margin and adjacent continental rise (Kidd et al. 1995), and the fossil age (Landing et al. 2003) is consistent with eruption in the Ordovician just before collision began. Syn-collisional normal faults oriented parallel to the regional Taconic thrust fabric are present in the adjacent foreland and have been interpreted to be related to extension of the lower plate during the Taconic collisional event (Bradley and Kidd 1991).

\section{Jonestown Volcanics (Pennsylvania)}

The Jonestown Volcanics are located within the outcrop of the Hamburg Klippe (Fig. 7), a Taconic thrust sheet remnant (Lash 1986), and are interpreted on the basis of the detailed mapping of Ashcroft (2002) to form a separate out-ofsequence thrust sheet remnant above the transported sedimentary strata of the Hamburg Klippe (Fig. 9). The Jonestown Volcanics consist of basaltic pillow lavas, and diabase (dolerite) (Fig. 10); the only sedimentary material clearly associated with the volcanics, like Starks Knob, is limestone (Fig. 11). The limestone has not been fossil dated, but is inferred to be mid- 


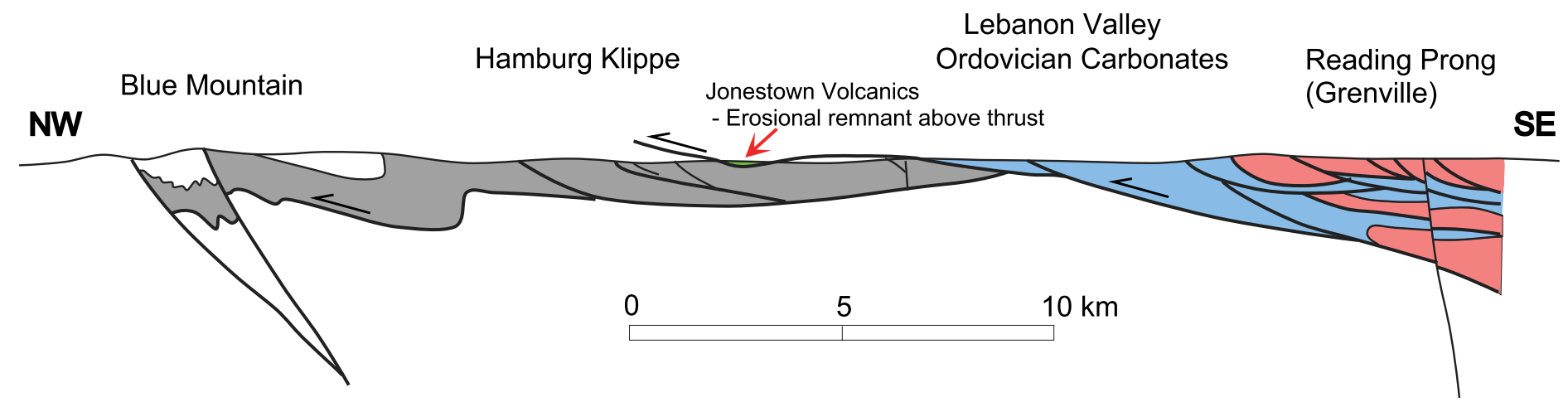

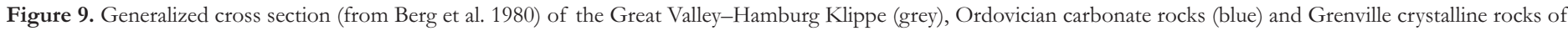

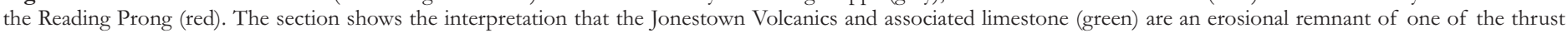
sheets of Ordovician carbonate rocks in the Lebanon Valley. No vertical exaggeration. Location of section line shown on Figure 7.

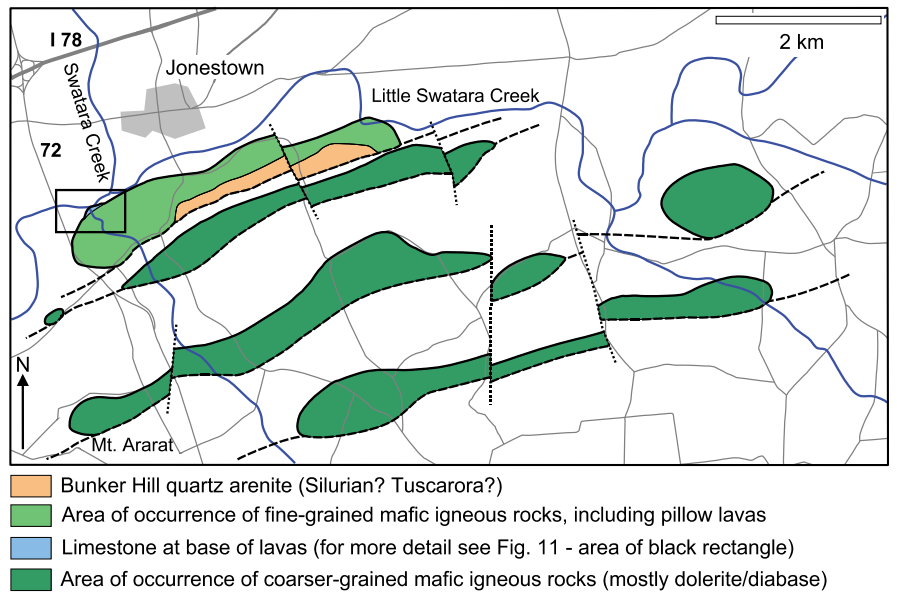

Figure 10. Map of the Jonestown Volcanics showing the extent of mafic igneous rocks from outcrop mapping (Ashcroft 2002). Black rectangle is area of detailed geological map (Fig. 11). Inferred faults affecting the volcanics shown by thick lines: solid - early thrusts, folded; dashed - later thrust faults; dotted - cross faults. Uncoloured area - bedrock sedimentary strata of the Hamburg Klippe structurally underlying the volcanic rocks. Quartz arenites of the Bunker Hill ridge are inferred to overlie the Jonestown volcanic rocks unconformably and to be of Silurian age.

Ordovician based on lithological resemblance to the Annville Limestone in the nearest passive margin-derived thrust sheet in the Lebanon Valley to the southeast (Ashcroft 2002). Quartz arenites of the Bunker Hill Ridge (Fig. 10) are inferred to overlie the Jonestown volcanic rocks unconformably, and to be of Silurian age. Local evidence for contemporaneous extensional stress orientation is lacking in the volcanic rocks, although there are hints that lower plate foreland normal faulting (Shanmugan and Lash 1982), like that better documented in New York and Quebec (Bradley and Kidd 1991), occurred in the platform strata to the northwest. We think that the Jonestown Volcanics and Starks Knob had similar sites of eruption on the outer Laurentian shelf (see geochemical characterization below), and that both had Taconic (Ordovician) thrustemplacement histories.

\section{Morel Sills and Ghost Dykes (Wopmay Orogen)}

The Coronation Supergroup exposed in the Wopmay Orogen is the origin of the model first presented by Hoffman (1987)

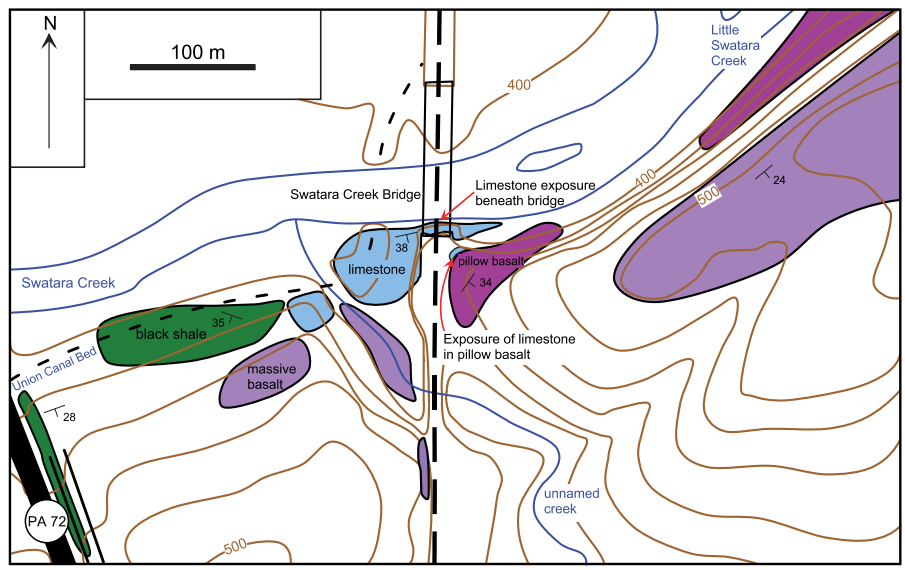

Figure 11. Geological outcrop map of the vicinity of the abandoned Reading Railroad bridge over Swatara Creek, south of Jonestown, PA. The locality of the pillow basalt containing limestone is shown. Contour interval 20 feet. From Ashcroft (2002).

of foredeep sedimentation and magmatism. There, a basement and rift sequence on the northwest margin of the Slave Craton is overlain by a shallow marine passive margin sequence. This passive margin sequence is swamped by overlying, thick greywacke turbidites and other clastic rocks that form a collisional foreland basin fill. The Morel Sills (Fig. 12) intruded the passive margin and foredeep sedimentary section and were emplaced just prior to foreland-directed thrusting. Hoffman (1987) noted a lack of evidence for pre-collisional normal faulting besides that associated with pre-passive margin continental rifting, but Hildebrand and Bowring (1999) and Hildebrand et al. (2010) concluded that the substantial $(\sim 200 \mathrm{~km})$ margin-parallel distribution of the sills reflects extension perpendicular to the margin, and to the collisional thrusts and fold hinge lines.

The ca. $1884 \mathrm{Ma}$ Ghost dykes, a series of NNE-trending mafic dykes, intruded the Slave Craton south of the main part of the Wopmay Orogen (Fig. 12), and are sub-parallel with it (Frith 1993). These dykes have been correlated, based on position, orientation, and geochemistry, with the Morel Sills (Hoffman 1987; Hildebrand et al. 2010). Although there are presently no very precise isotopic ages for the Morel Sills, precise 


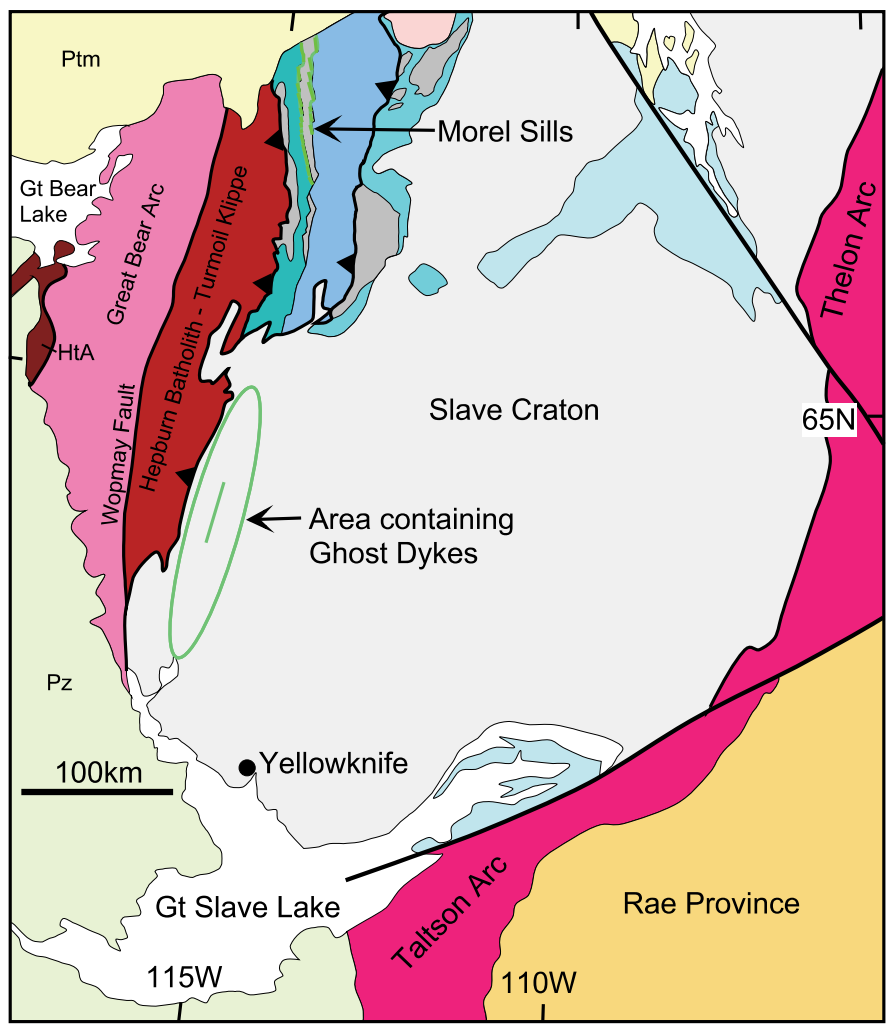

Coronation Supergroup units

Calderian foredeep strata

transported slope/rise strata

transported shelf strata

shelf strata not transported undifferentiated strata of paleoProterozoic age

Figure 12. Location and orientation of the Morel Sills and Ghost Dykes in the Calderian (Wopmay) Orogen and adjacent Archean Slave Craton. Map simplified after Hoffman (1987, 1988); Frith (1993); Hildebrand et al. (2010). HtA - Hottah Arc, Ptm - Mesoproterozoic cover, Pz - Paleozoic cover.

dates for the Ghost dykes of ca. $1884 \mathrm{Ma}$ were reported by Buchan et al. (2009). Hildebrand et al. (2003) and Davis and Bleeker (2007) concluded the Ghost dyke swarm was related to lower plate breakoff during the convergence and collision of the Slave Craton with an arc during the Wopmay Orogeny.

\section{Molson Dykes (NW Superior Craton Margin)}

The ca. 1883 Ma Molson Dykes are a series of NE-striking, nearly vertical mafic dykes that occur in the NW margin of the Superior Province, in a zone about $150 \mathrm{~km}$ wide adjacent to and parallel with the Thompson Belt, part of the larger Circum-Ungava (Trans-Hudson) Orogen (Fig. 13). Hoffman (1988) suggested that they were emplaced in a foredeep basin position during lower plate flexure and convergence on this margin. Their orientation is parallel to the regional orogenic trend in the adjacent Thompson Belt and craton margin, and their age is now very well constrained as in the same range as orogenic shortening and magmatism in the Thompson Belt (age compilation and discussion in Minifie 2010; see also Hea-

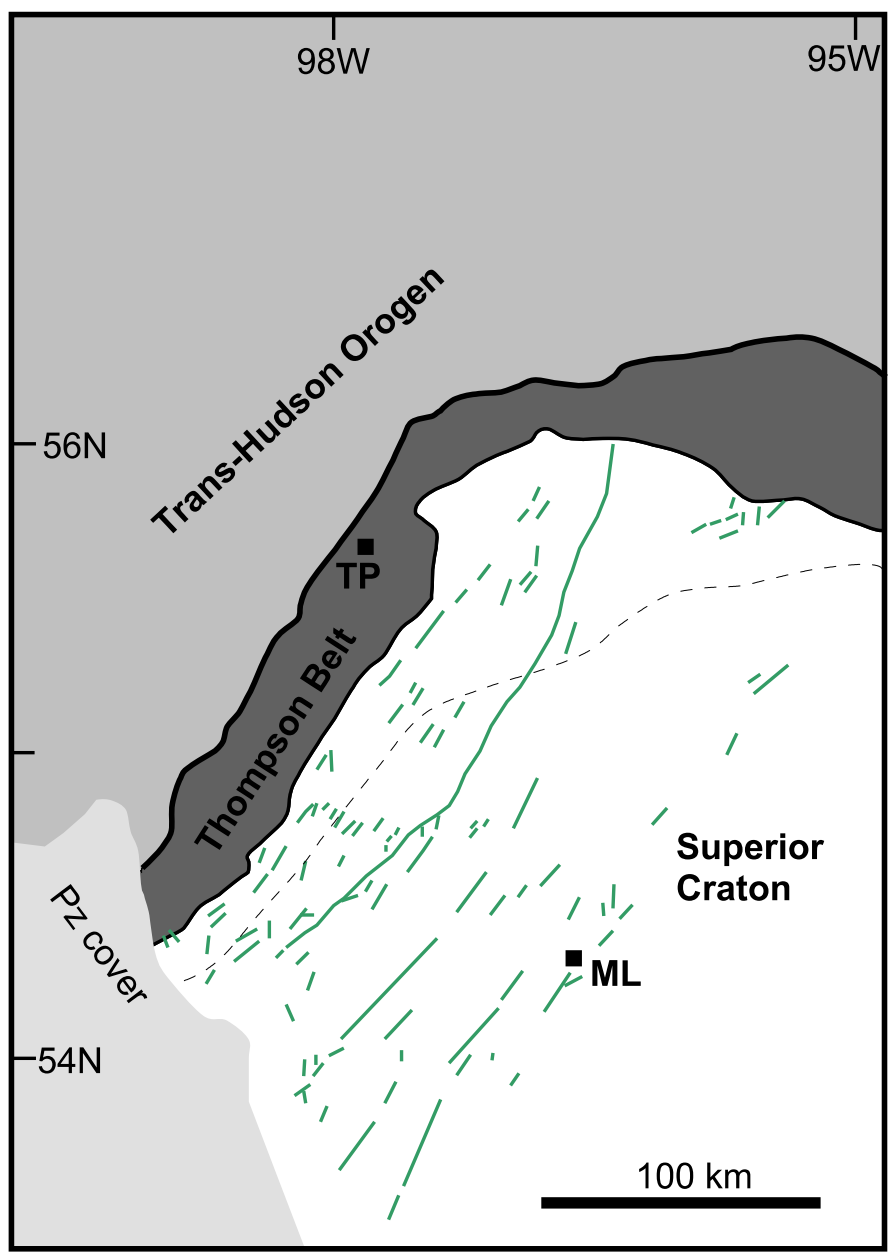

Figure 13. Distribution of the Molson Dykes (green lines) in the Superior Craton adjacent to the deformed rocks of the Proterozoic Thompson Belt. Dashed grey line - SE border of Pikwitonei granulite. ML - Molson Lake, TP - Thompson. Adapted from Minifie (2010).

man et al. 2009) showing that these extensional structures developed parallel with the trench or thrust strike direction, and coeval with the orogenic shortening event.

\section{Flaherty Formation (Belcher Islands, Canada)}

The Proterozoic Flaherty Formation of the Belcher and Sleeper Islands in Hudson Bay (Fig. 14) are a series of mafic lavas above a rift and passive margin stratigraphic sequence that includes older subaerial volcanic rocks overlain by arkose and shallow marine carbonate rocks that pass up into argillite, shale, and iron formation (Legault et al. 1994). The Flaherty Formation is dominated by pillows and contains interbedded volcaniclastic sedimentary rocks indicating a subaqueous eruptive environment (Ricketts et al. 1982; Legault et al. 1994). The overlying sedimentary rocks are euxinic shale and turbidites. Hoffman (1987) interpreted this to be a foredeep sequence nearly identical to that seen in the Wopmay Orogen (the magmatism here equivalent to the Morel Sills). Two U-Pb ages of $1870 \mathrm{Ma}$ (M. Hamilton in Minifie 2010) have been obtained from the Haig Sills, which occur both in the Belcher and Sleeper Islands, and are thought to be the intrusive equivalents to 
the volcanics. The regional distribution of the Flaherty Formation and Haig Sills and their magmatic correlatives in the Chukotat Group in the Ottawa Islands and Cape Smith Belt (Hynes and Francis 1982; Hynes et al. 1994; Dunphy et al. 1995; Baragar 2007, 2008), over a distance of hundreds of kilometres along the Superior Craton margin, implies a thrustparallel extensional structure association.

\section{GEOCHEMISTRY}

We have selected and compiled 330 geochemical analyses of volcanic and shallow intrusive mafic rocks including basalt, basalt-andesite, alkaline basalt, and foidite from the foreland magmatic settings described above (Fig. 15). These are presented in several commonly used trace element discrimination diagrams to distinguish between plume-influenced and slab detachment types. Sources of the original analyses are listed in Table 1; refer to these sources for the analytical methods used.

Although some analyses are of young, relatively pristine rocks unaltered by weathering or metamorphism, many older ones are not, so only immobile trace elements, generally stable during weathering and low-grade metamorphism (Pearce 1996), are used for comparison purposes. All rocks presented here have been reported as having experienced greenschist facies metamorphism or less, except for the rocks from the Piling Group (discussed below) that reached amphibolite facies and for which there may be less confidence that the original immobile element concentrations have remained significantly unchanged since magmatic emplacement.

Discrimination diagrams have been shown to work over a range of degrees of partial melting of the mantle source in natural examples (e.g. Shervais 1982; Pearce 1996) in that immobile element ratios in magmas are not significantly changed unless there are high differences in degree of partial melting from one source. If significant differences in partial melting occur within a suite then a transdiscriminant pattern (suite samples plot across tectonic field boundaries) may result. They also permit discrimination in the face of compositional changes induced by some degree of fractional crystallization, as long as the samples chosen are basaltic in composition (see Pearce 2014).

\section{Normalized Diagrams}

The chondrite- and MORB-normalized diagrams illustrate some important differences between the Rhine and Maine types. First, Rhine-type volcanic rocks are significantly more enriched in LREEs than the Maine-type indicating a more enriched mantle source (or a lower degree of partial melting); the flatter Maine-type patterns indicate a more depleted mantle source (or a higher degree of partial melting; Fig. 16). The Rhine-type patterns on the MORB-normalized diagram (Fig. 17A) are consistent with those shown by the chondrite-normalized diagram. Second, many of the Maine-type samples on the MORB-normalized diagram display $\mathrm{Ta}-\mathrm{Nb}$ (or just $\mathrm{Ta}$ for the Flaherty Formation) negative anomalies (Fig. 17B). The $\mathrm{Ta}-\mathrm{Nb}$ negative anomaly, typically associated with supra-subduction zone environments, and evident in the Devonian Maine rocks may be the result of partial melting of a subduc-

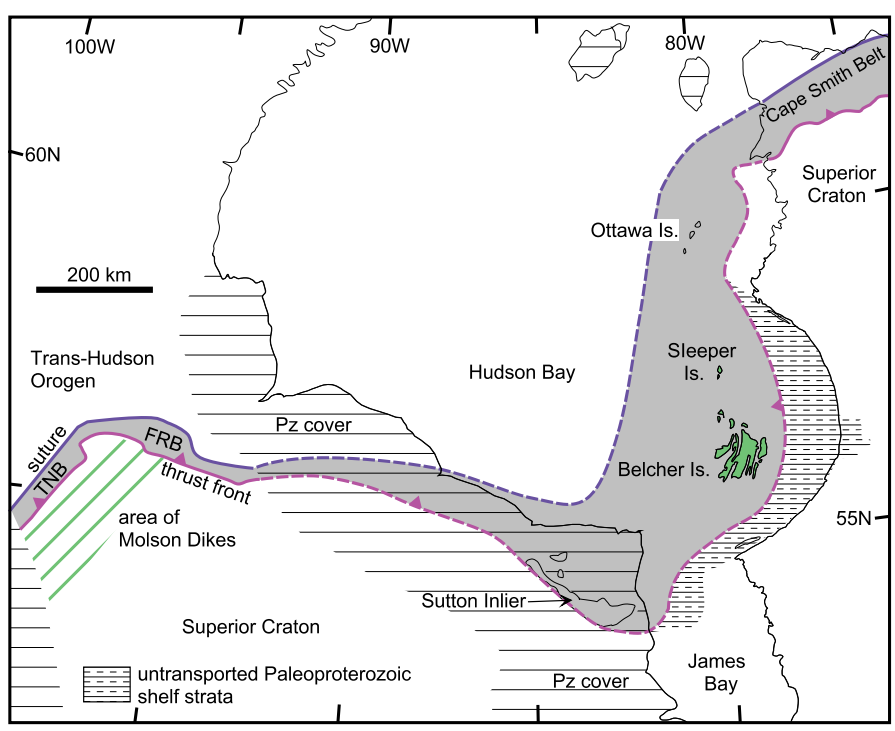

Figure 14. Location of the Belcher and Sleeper Islands in eastern Hudson Bay, within the fold and thrust belt of Paleoproterozoic age on the north side of the Archean Superior Craton. FRB - Fox River Belt, Pz - Paleozoic cover, TNB Thompson Belt.

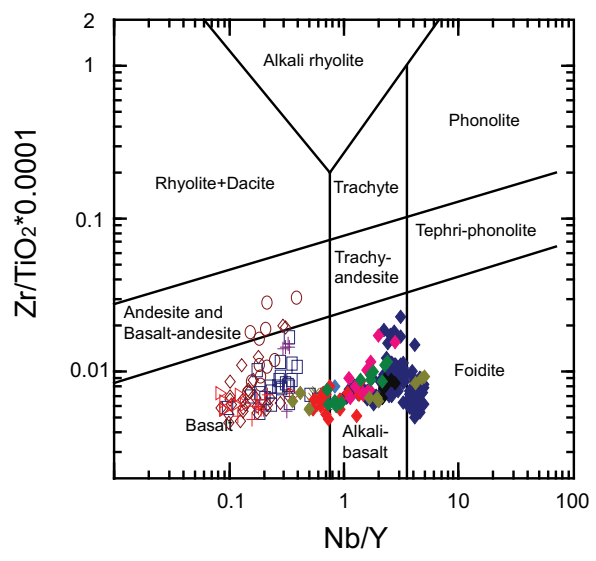

- Rhine Graben

- East Anatolia type1

- East Anatolia type 2

$\checkmark$ Penghu Islands

- Petit Spots

- Cortlandt Complex

- Bravo Formation

Maine Acadian

Starks Knob

Jonestown Volcanics

+ Morel Sills

- Ghost Dykes

Molson Dykes

Flaherty Formation

Figure 15. Classification diagram of Winchester and Floyd 1977.

tion-modified sub-continental mantle (Dostal et al. 1989; Hon et al. 1992; Keppie and Dostal 1994; Schoonmaker et al. 2011). In contrast, all but one of the Starks Knob samples lack sufficient Th to be analyzed, so do not show an anomaly (Fig. 17C). The very low Th concentrations in the Starks Knob samples indicate that the sub-continental mantle at its eruption site was not exposed to a prior supra-subduction event. The Jonestown samples show significant scatter, two of them suggest a $\mathrm{Ta}$ negative anomaly, but there is no corresponding anomaly for $\mathrm{Nb}$ (Fig. 17C). When the Starks Knob and Jonestown samples are removed from the MORB-normalized diagram, the remaining Maine-type samples show a more uniform pattern with distinct $\mathrm{Ta}-\mathrm{Nb}$ negative anomaly (Fig. 17D). This raises the possibility that the Starks Knob and Jonestown rocks (both formed on the Laurentian margin, with Grenville basement) experienced a somewhat different history than those in Maine and those in Proterozoic orogens in Canada. Third, Ti/Yb 

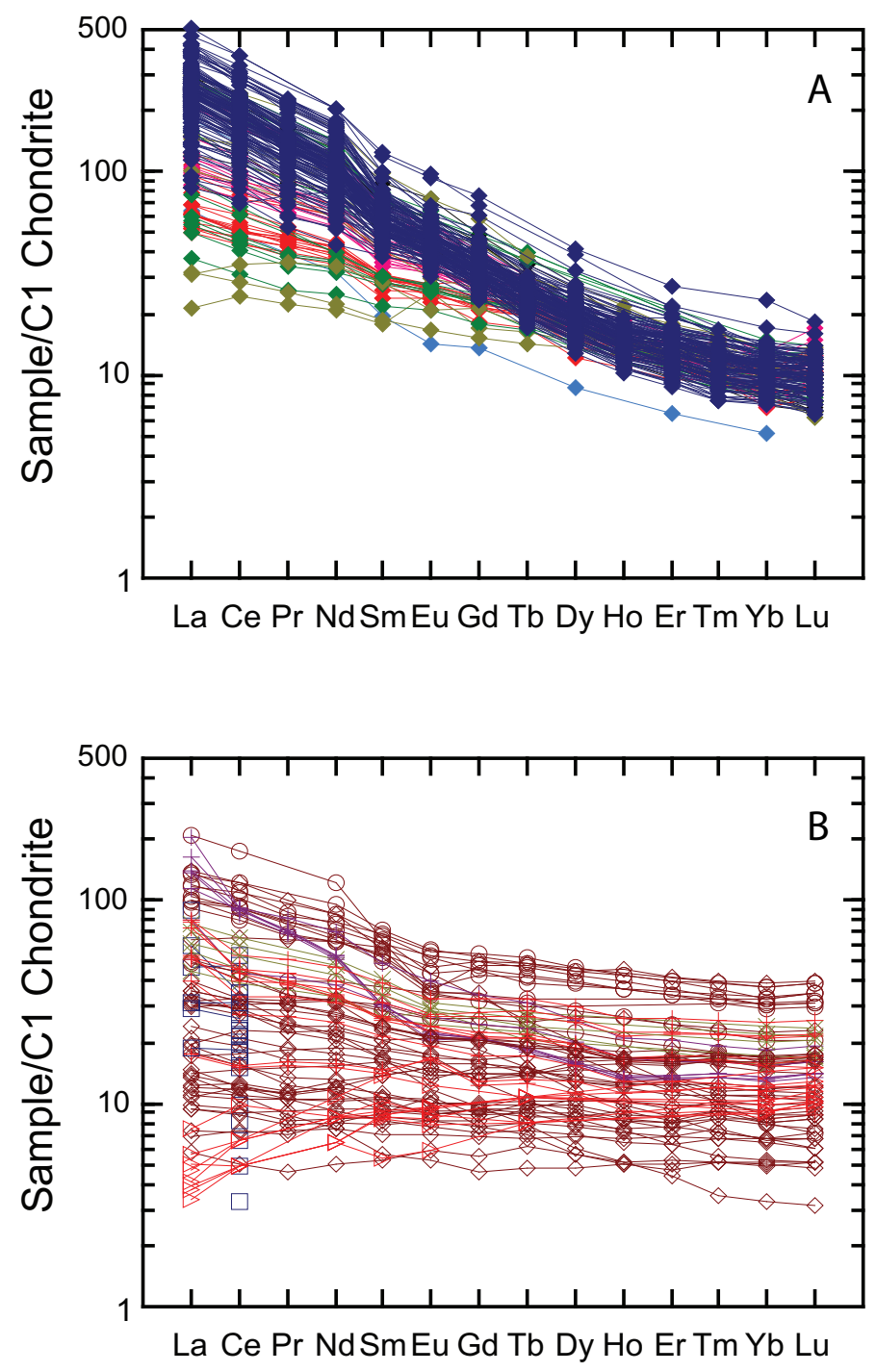

Figure 16. Chondrite-normalized diagrams: A - Rhine-type, B - Maine-type. See Figure 15 for symbol legend.

ratios (normalized) are higher in the Rhine-type rocks than those in the Maine-type rocks (3.33 vs. 1.24, respectively).

\section{Tectonic Discrimination Diagrams}

Several tectonic discrimination diagrams are presented to illustrate correlations and differences between the suites and to infer possible processes involved. What is clear is that there is a nearly complete separation of Rhine- and Maine-type foredeep rocks (Figs. 18-23) in all of these diagrams.

\section{$\mathrm{Nb}-\mathrm{Zr}-\mathrm{Y}, \mathrm{Nb} / \mathrm{Y}-\mathrm{Zr} / \mathrm{Y}$, and $\mathrm{Hf}-\mathrm{Th}-\mathrm{Nb}$ Diagrams}

The Nb-Zr-Y diagram of Meschede (1986) discriminates between various MORB types and plume-influenced tectonic settings based on the concentration of $\mathrm{Nb}$ relative to $\mathrm{Zr}$ and $\mathrm{Y}$ (Fig. 18). In lavas derived from enriched mantle, Nb concentrations are high, whereas lavas from depleted mantle (MORB and arc environments) have lower $\mathrm{Nb}$ concentrations. The separation between Maine and Rhine types indicates they are partitioned between these different mantle types. Less obvious in this diagram is that the $\mathrm{Zr} / \mathrm{Nb}$ ratio is higher in the Mainetype rocks than in the Rhine-type rocks (15.7 vs. 3.26, respectively).

The Nb/Y-Zr/Y diagram (Fitton et al. 1997) is designed to discriminate between MORB and plume-influenced lavas based on $\mathrm{Nb}$ concentrations, serves a similar purpose to Meschede's diagram, but more clearly separates the Maine and Rhine types where the Rhine types have more enriched concentrations of $\mathrm{Zr}$ and $\mathrm{Nb}$ relative to $\mathrm{Y}$. Significant variation in $\mathrm{Zr} / \mathrm{Y}$ ratios evident in the plot, specifically the Acadian Maine samples, was attributed to systematic analytical bias in the compiled datasets used (Schoonmaker et al. 2011).

Wood's (1980) diagram (Fig. 20) makes use of similar processes (depletion of $\mathrm{Nb}$ in depleted mantle) as the other $\mathrm{Nb}-\mathrm{Zr}-\mathrm{Y}$ diagrams, but uses the ratio $\mathrm{Nb}$ to $\mathrm{Hf}$ to discriminate between volcanic rocks derived from enriched and depleted mantle. Low $\mathrm{Nb}$ concentrations relative to $\mathrm{Hf}$ are characteristic of volcanic rocks from depleted mantle whereas high concentrations are characteristic of an enriched mantle source for volcanics. Rocks that are enriched in Th, typical of subduction zones or from mantle sources that have been otherwise enriched in Th (e.g. previously subduction-modified), plot down to the left, away from the mantle source fields. Similar to the $\mathrm{Nb}-\mathrm{Zr}-\mathrm{Y}$ diagrams, in this the mantle sources between Maine (depleted) and Rhine (enriched) types are nearly completely separated (some Molson dykes from Heaman et al. (2009) have Nb or Hf concentrations below detection limits).

\section{Ti-V Diagram}

The Ti-V diagram (Fig. 21) of Shervais (1982) is generally used to identify arc environments based on the difference in behaviour of $\mathrm{V}$ depending on fluid content of the mantle source. V becomes more incompatible when fluid contents are high, such as occurs in supra-subduction zones that generally have $\mathrm{Ti} / \mathrm{V}$ ratios below 20 . In alkaline rocks, $\mathrm{Ti} / \mathrm{V}$ ratios are high, above 50. Continental tholeiite may have Ti/V ratios below 50. In this diagram there is a strong separation of Maine- and Rhine-type rocks although a significant number of the Rhine samples plot at $\mathrm{Ti} / \mathrm{V}$ ratios slightly below 50 . Most of the Maine-type suite has $\mathrm{Ti} / \mathrm{V}$ ratios between 20 and 50, where MORB, back-arc basins, and continental tholeiites typically plot, although a significant number of the Molson dykes plot in the arc field.

\section{Ti-Zr-Y Diagram}

Pearce and Cann's (1973) diagram (Fig. 22) discriminates between within-plate settings and MORB and volcanic arc environments. Within-plate magmas include plume or hotspot types and result from higher relative concentrations of $\mathrm{Ti}$ and $\mathrm{Zr}$ to $\mathrm{Y}$. MORB and volcanic arc magmas have lower relative amounts of $\mathrm{Ti}$ and $\mathrm{Zr}$. The Rhine-type rocks almost exclusively plot in the within-plate field, consistent with their patterns on the MORB-normalized diagram (Fig. 17), whereas the Maine-type rocks plot across the MORB and arc fields. 

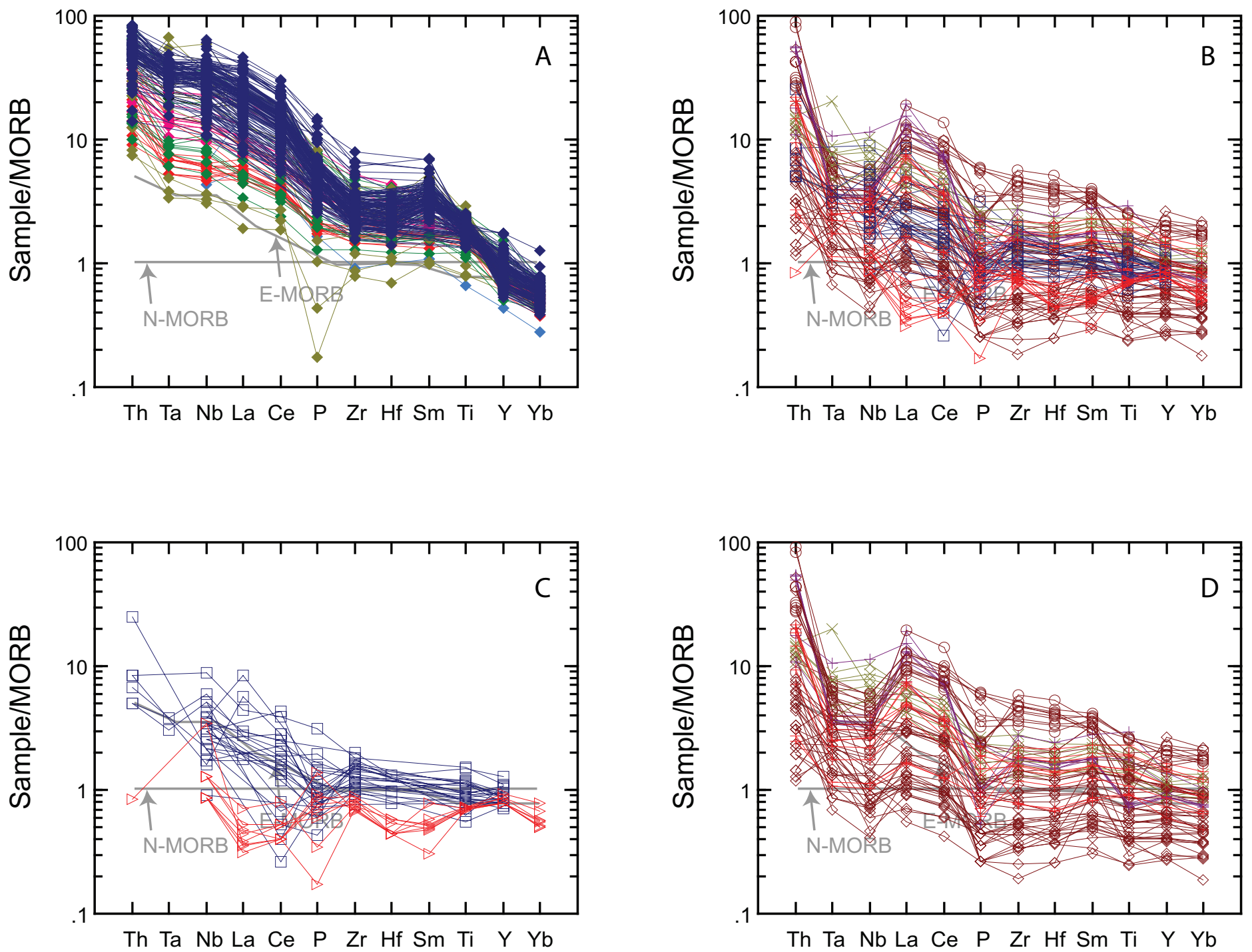

Figure 17. MORB-normalized diagrams: A - Rhine-type, B - Maine-type, C - Starks Knob and Jonestown samples only, D - Maine-type with Starks Knob and Jonestown samples removed. See Figure 15 for symbol legend.

\section{$\mathrm{TiO}_{2} / \mathrm{Yb}-\mathrm{Nb} / \mathrm{Yb}$ Diagram}

$\mathrm{The} \mathrm{TiO}_{2} / \mathrm{Yb}-\mathrm{Nb} / \mathrm{Yb}$ diagram (Fig. 23) of Pearce (2008) is useful for the purposes of this paper as it discriminates between magmas from deep mantle and shallow mantle sources. During melting of shallow spinel peridotite, Ti and $\mathrm{Yb}$ enter the melt equally but garnet in deep mantle retains $\mathrm{Yb}$ (Pearce 2008, 2014), so Ti/Yb ratios are higher in lavas from deep mantle sources, relative to those from shallow mantle sources. The Rhine and Maine types in the selected example suite are completely separated in this diagram, in both $\mathrm{TiO}_{2} / \mathrm{Yb}$ and $\mathrm{Nb} / \mathrm{Yb}$ ratios.

\section{DISCUSSION \\ Magma Sources and Tectonic Associations}

From the striking chemical separation of the Rhine and Maine types it is probable that these two types of foreland magmatism were generated under substantially different conditions and result from different processes. Additionally, the degree of partial melting for the Rhine types is inferred to be less than the Maine types; the Rhine types have significantly lower $\mathrm{Nb} / \mathrm{Y}$ (or $\mathrm{Nb} / \mathrm{Yb}$ ) and $\mathrm{Zr} / \mathrm{Y}$ ratios than the Maine types (Figs. $16,17,18,22,23)$. High Hf concentrations in Figure 20 and generally higher $\mathrm{Y}$ concentrations relative to $\mathrm{Cr}$ (not figured) also support this conclusion (see Pearce 1982). While there are internal variations in element concentrations of the two types (e.g. the overall trends in the Figs. 18, 20, and 21), the internal trends do not correlate between the groups suggesting that variations in partial melting cannot explain the differences between the two types. The lack of apparent intermediate suites (see especially Fig. 23) also supports the idea that the differences in partial melting do not explain these differences.

Two main tectonic processes have been proposed by previous workers in these areas to explain the origin of these suites: plume (or at least sub-lithospheric mantle upwelling) influence, and slab detachment. In some of these examples, different authors have put forward these competing hypotheses for the 


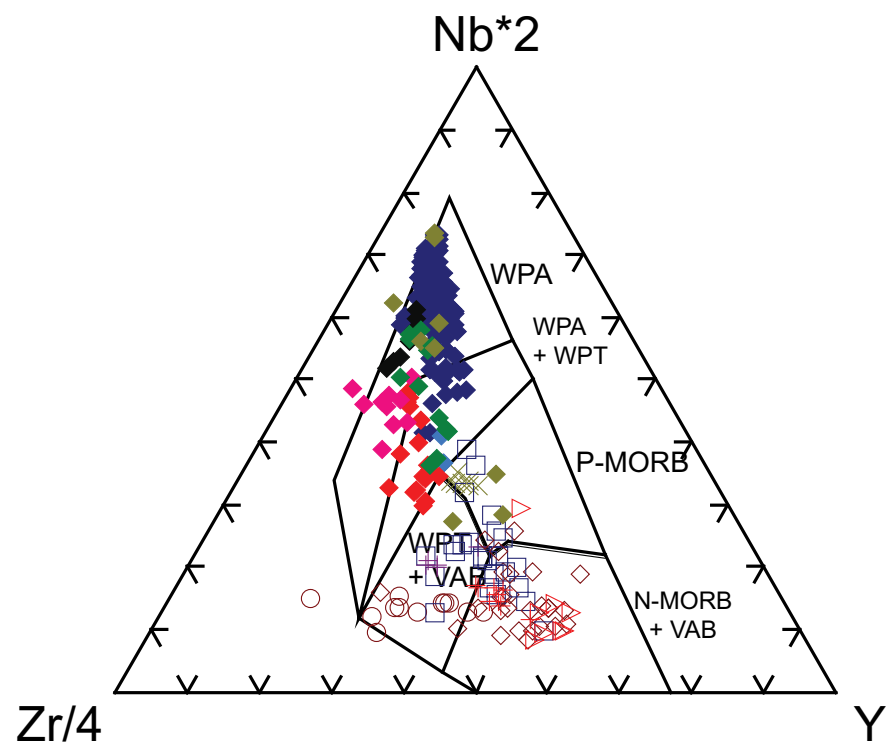

Figure 18. Nb-Zr-Y diagram of Meschede 1986. See Figure 15 for symbol legend.

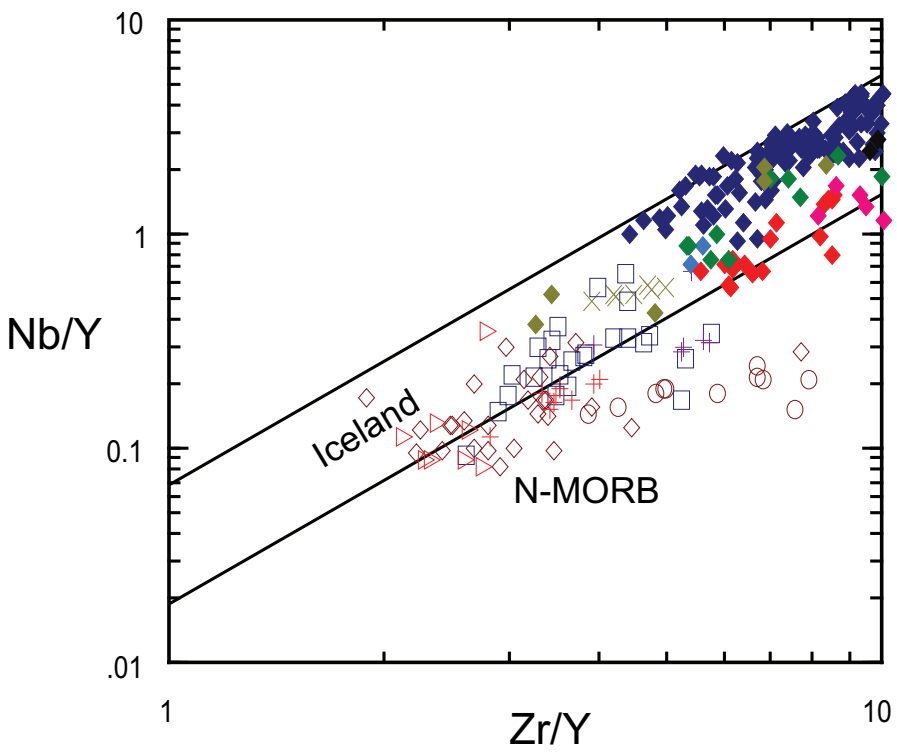

Figure 19. $\mathrm{Nb} / \mathrm{Y}-\mathrm{Zr} / \mathrm{Y}$ diagram of Fitton et al. 1997. See Figure 15 for symbol legend.

same setting, particularly in the case of the Rhine Graben.

Multiple hypotheses have been proposed for the origin of magmas erupted in the Rhine Graben including partial melting of metasomatized asthenospheric mantle, partial melting of the base of the lithosphere (thermal boundary layer), and partial melting of mantle plumes (Bogaard and Wörner 2003; Haase et al. 2004 and references therein; Jung et al. 2006; Shaw and Woodland 2012; Jung et al. 2013). In some of this work, largely based on isotopic ratio differences, the WestervaldEifel area is generally considered to have formed primarily from a mantle plume source, whereas the Vogelsberg area formed from a thermal boundary layer source at the base of the lithosphere. Our compiled dataset contains samples from both these areas that show no separation based on trace ele-

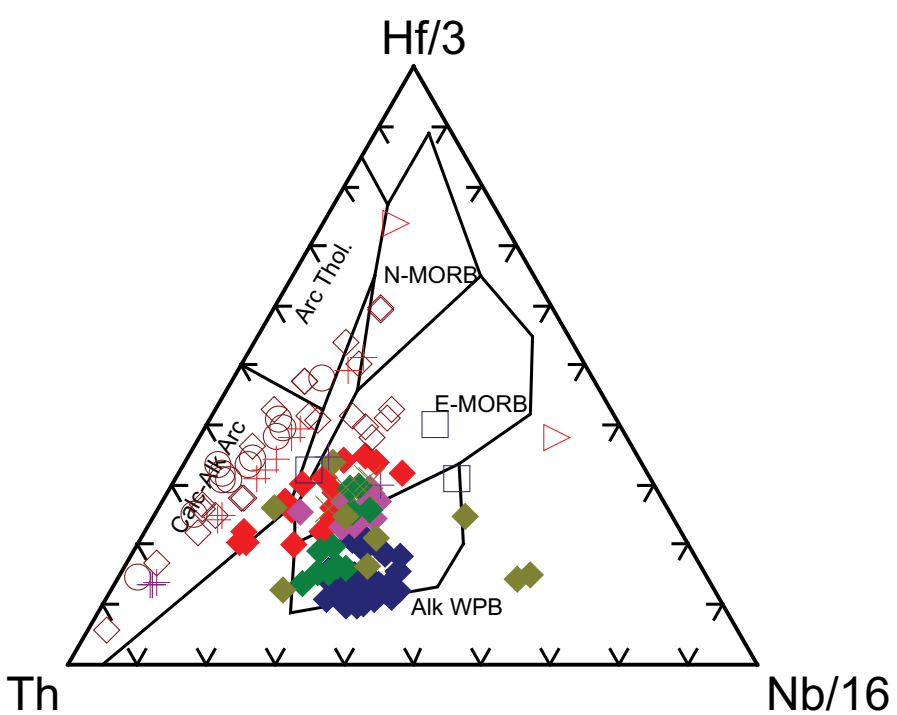

Figure 20. Hf-Th-Nb diagram of Wood 1980. See Figure 15 for symbol legend.

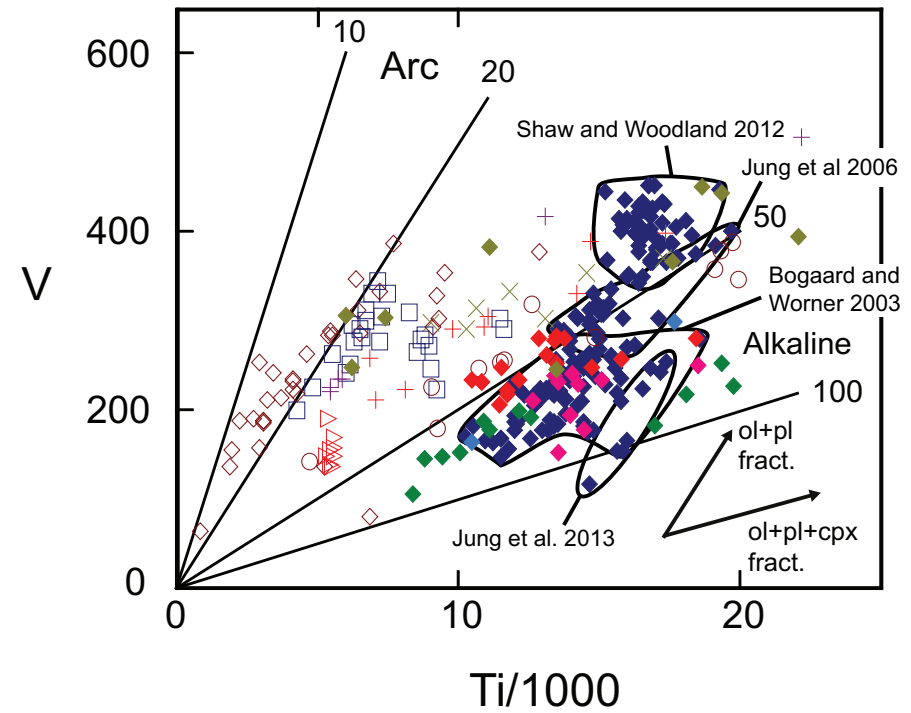

Figure 21. Ti-V diagram of Shervais 1982. See Figure 15 for symbol legend.

ment concentrations. Importantly, the $\mathrm{TiO}_{2}-\mathrm{Yb}-\mathrm{Nb}$ concentrations (Fig. 23) indicate rocks from both areas were derived from garnet peridotite, whereas Haase et al. (2004), based on isotopic ratios, concluded that the Vogelsberg rocks were sourced from spinel peridotite of the thermal boundary layer at the base of the lithosphere, although they infer that this melting occurred in the larger context of mantle plume activity.

In SE Turkey, Ekici et al. (2012) divided the Siverek Plateau lavas into two groups based on major and trace element concentrations: Group 2 lavas generally having higher concentrations of incompatible trace elements. In our plots, the Group 1 lavas plot further from the Rhine samples than do the Group 2 lavas, but both are still consistent with that group. The Karacadağ Volcanic Complex has alternatively been interpreted to have contributions from the Afar plume (Krienitz et al. 


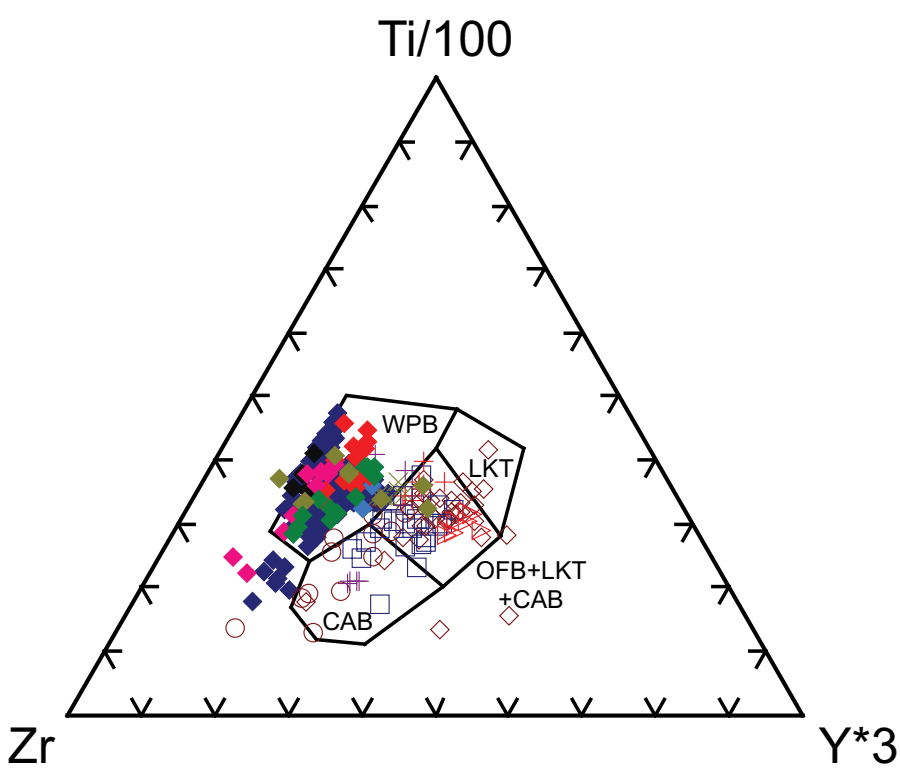

Figure 22. Ti-Zr-Y diagram of Pearce and Cann 1973. See Figure 15 for symbol legend.

2009) or a separate mantle upwelling (Keskin 2003; Ekici et al. 2012), and isotopic studies give conflicting interpretations regarding the role of mantle plumes in northern Arabian Peninsula volcanism. Ekici et al. (2012) reported Pb isotope ratios that do not match Afar plume compositions, while Krienitz et al. (2009) concluded that an Afar contribution is consistent with part of a mixed magma source. Ekici et al. (2012) argued for Maine-style magmatism as the origin of Karacadağ volcanic rocks, with lithospheric thinning of the margin resulting from tension from the subducting Tethyan oceanic lithosphere to the north, and Keskin (2003) similarly invoked a slab breakoff mechanism, although the Karacadağ Plateau is peripheral in his model. Evidence against this mechanism is a reported lack of appropriately oriented extensional deformation in the area (Camp and Roobol 1992), and the fact that there are young, directly associated extensional structures in the area of this magmatism, oriented at a high angle to the nearby thrust belt (Şengör and Kidd 1979; Pearce et al. 1990). Perhaps the earliest magmatism here was through fractures controlled by slab-pull stresses (Ekici et al. 2012), and converted to the now dominant convergence-controlled fractures for the later eruptions. The early volcanic rocks, however, are not known to include examples falling within the fields of Mainetype compositions, although some of the Group 1 lavas of Ekici et al. (2012) do plot closer to those fields. Perhaps the later part of a transition to Rhine-type magmas is preserved here.

Near Taiwan, the mid-late Miocene basalt of the Penghu Islands are interpreted (Chung et al. 1994; Wang et al. 2012) to have formed from asthenospheric mantle, both from lithospheric extension and from mantle upwelling. The amount of lithospheric extension of the crust required to bring asthenosphere into the melting regime following thinning of the lithospheric mantle would likely produce much greater extension of the upper crust than is evident (Chou and Yu 2002) west of

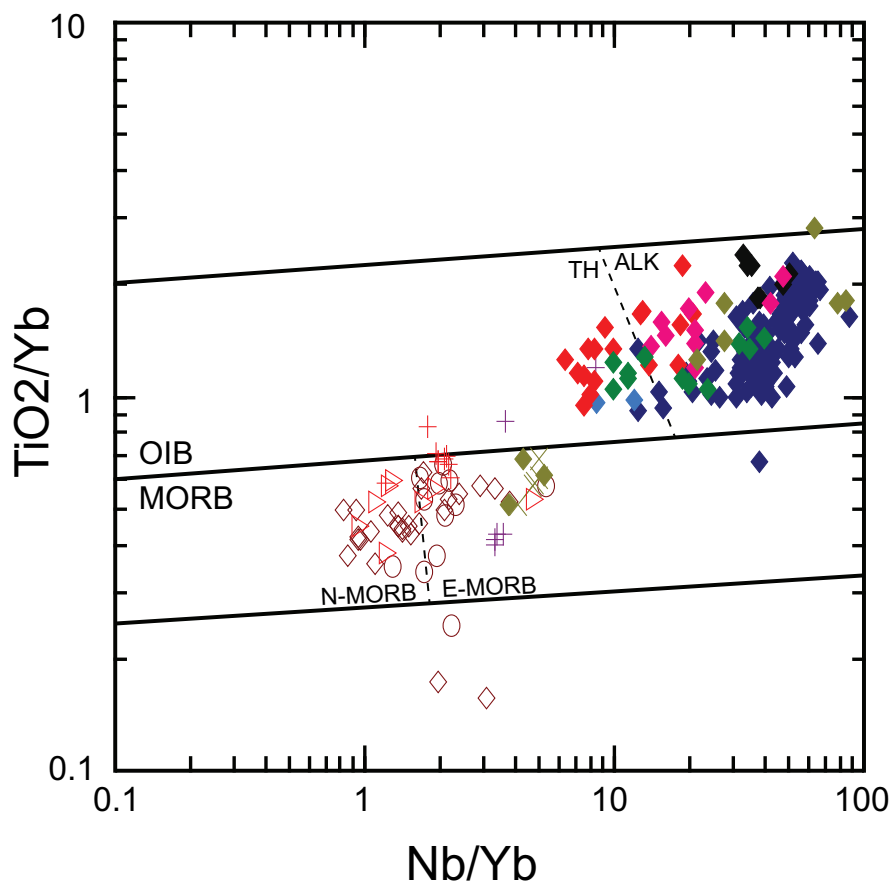

Figure 23. $\mathrm{TiO}_{2} / \mathrm{Yb}-\mathrm{Nb} / \mathrm{Yb}$ diagram of Pearce 2008. See Figure 15 for symbol legend.

Taiwan for the 16-8 Ma time interval of the volcanism. We have strong doubts that the Penghu Islands volcanics ought to be regarded as foreland basin magmatism, based on the coherent set of mid-late Miocene ages, including the fossil ages of interbedded sedimentary rocks, and their consistency with the dissected and planated topography of the volcanic field exposed in the islands, where no evidence of young constructional volcanic landforms is visible. At the rate of plate convergence across the Manila Trench, presently $90 \mathrm{~mm} / \mathrm{a}$ in southern Taiwan opposite the Penghu Islands (DeMets et al. 2010), the accretionary toe of the subduction system would have been nearly $300 \mathrm{~km}$ away from the East China passive continental margin only 3 M.y. ago, and much farther at 8 M.y. (Fig. 5). Even with the slower convergence rate for the last 8 M.y. given by Sibuet et al. (2002), the distance from the trench at 8 Ma would have exceeded $500 \mathrm{~km}$. Stratigraphic and other geological evidence indicates that the diachronous collision began at about $5 \mathrm{Ma}$ ('Teng and Lin 2004; Huang et al. 2006). Nevertheless, because they have been previously suggested to be foreland magmatism, have both good geochemical and structural data sets, and because they provide a useful demonstration of the limits of discrimination possible from geochemical compositions, we included the Penghu volcanic rocks (if only as an object lesson) in our suite of possible examples. The geochemical characteristics of the magmas indicate that if they are included as foreland magmatism, they would belong to the Rhine-type group. We think that an independent mantle upwelling is a more likely explanation than others for the properties and localization of the Penghu Islands magmatism whether or not they have a relationship to the Taiwan foreland.

The Japan Trench petit-spot area is similar in geochemical characteristics to the other Rhine-type occurrences, but it cur- 
rently has rather weak evidence of the associated extensional structures. The overall distribution of the volcanic rocks does not show any preferred distribution along the belt of outer trench slope (trench-parallel) normal faulting, which suggests it is not associated primarily with those faults. Hirano et al. (2006) and Hirano (2011) suggested an origin from fracturing caused by lithospheric fore-bulge flexure, which should trend SW-NE parallel with that feature. We think the WNW-ESE orientation of the envelopes to two of the three volcanic areas, and the same alignment of spots in the area of older volcanic rocks (group 3, Fig. 6; Hirano et al. 2006), do not support this hypothesis. The WNW-ESE alignments that are evident, if not prominent, rather suggest that magmas used extensional fractures produced by maximum compressive stress in the lithosphere in the direction of, and resulting from, convergence at the Japan Trench. At 4 M.y. ago, the older group (3 - Fig. 6) would have been in the position where the younger group (2) is presently located, and we note that this age progression, although with intermittent expression here, is the same as from Pacific plate motion over better known, larger hotspots (e.g. Hawaii). The other group (1) is admittedly not accommodated by this suggestion, unless the area affected by mantle upwelling is $400 \mathrm{~km}$ or more across.

The one ancient Rhine-type structure, the Cortlandt Complex-Beemerville zone in the New York Taconic thrust belt, has properties similar to its modern counterparts. It is of interest that it occurs spatially between the two Maine-type Taconic examples (Jonestown, Starks Knob), which we think were erupted through the outer Laurentian passive margin (with inferred Grenville crust and lithosphere) before their tectonic transportation, and that the Cortlandt magmas were also emplaced through that type of lithosphere after the Taconic foreland thrusts had been emplaced over it. The strong contrast in the geochemistry of the Cortlandt magmas with the two older Taconic examples is striking, and also is suggestive that quite different processes generated the two types of foreland magmatism.

For the Maine-type examples, it is significant that for those where the orientations of contemporary extensional structures are known (Maine Acadian, Starks Knob, Ghost Dykes, Molson Dykes) or can be inferred from asymmetric regional extent (Morel Sills, Flaherty Formation-Haig Sills), the extensional fault and fracture orientations parallel the trench or thrust front, consistent with a slab pull or detachment mechanism.

Currently there is debate concerning the subduction polarity of the Acadian Orogeny in Maine. The west-dipping model requires the Piscataquis Volcanic Belt and associated magmatism to have occurred in a far back-arc region (van Staal et al. 1998) and to have been caused by shallow subduction (van Staal et al. 2009), and consequently not an example of foreland magmatism. In contrast, Bradley et al. (2000), Bradley and Tucker (2002), and Schoonmaker et al. (2005, 2011) have argued for an east-dipping subduction, placing Piscataquis belt volcanism in the foreland region of the lower plate, with emplacement slightly preceding the NW-migrating orogenic front. Discussion of these interpretations, and others (Eusden et al. 2000), was made by Schoonmaker et al. (2011). Here, we emphasize one inconsistent consequence of the east-dipping interpretation. In the flat slab region of the Andean orogenic belt of Argentina, the crust of the Precordillera has undergone significant thickening and thrusting involving basement. Current thickness of the Precordillera crust exceeds $60 \mathrm{~km}$ (Ammirati et al. 2013) and given current erosion rates in the Precordillera that approach $100 \mathrm{~m} / \mathrm{M}$.y. (Walcek and Hoke 2012), this suggests that the Maine Acadian should have exhumed significantly buried metamorphic rocks if it had experienced a Precordilleran-type thickening. The Acadian of central and northern Maine and Gaspé only caused low-grade metamorphism of the rocks now exposed (e.g. Osberg et al. 1985) suggesting that such thickening did not occur and that back-arc magmatism caused by flat slab subduction is an unsatisfactory interpretation for the origin of Piscataquis Belt volcanism.

It is clear from numerous studies that magmas derived from partial melting of sub-continental lithospheric mantle can be heterogeneous and can also be influenced by prior subduction-related events during arc or microcontinent accretion. These prior events result in more depleted sub-continental mantle that can also have subduction geochemical signals (e.g. Pearce et al. 1990; Cloos et al. 2005). This geochemical pattern is characteristic of foreland magmatism of all the Maine-type examples, and so we infer for this type a slab-pull or detachment mechanism and shallow asthenospheric decompression partial melting, perhaps accompanied by some lithospheric partial melting.

\section{Other Examples}

Bradley (2008, his table 2) identified more occurrences of probable foredeep magmatism in his discussion of ancient passive margins but, as far as we are aware, those additional to the ones we discuss are mostly not at present as well-documented, nor are sufficient geochemical analyses available for many of them.

One that has recently been well-characterized in its geological setting and geochemistry is in the approximately $1900 \mathrm{Ma}$ Piling Group, which starts with a series of quartzitic, calc-silicate, and carbonate metasedimentary rocks of medium metamorphic grade that directly overlie Rae Craton basement in the Trans-Hudson Orogen north of Hudson Bay (St-Onge et al. 2009; Rainbird et al. 2010). These metasedimentary rocks are overlain by a series of alkaline to tholeiitic pillowed basalt and associated mafic sills, and interlayered subaqueous volcaniclastic sedimentary rocks (Partin et al. 2014) affected by upper greenschist-facies metamorphism (Bravo Lake Formation). Overlying the volcanic rocks is a series of graded fine-grained sandstone and mudstone that locally contains conglomeratic beds in channels (Rainbird et al. 2010). This section suggests a passive margin stratigraphy that subsequently underwent subsidence concurrent with mafic volcanism. The occurrence of zircon of external origin in the overlying sandstone and subsequent deformation suggests an orogenic foreland setting as the Rae Craton margin was involved in collision during the TransHudson Orogeny (Partin et al. 2014). Most of the Piling Group samples plot with the main group of Rhine-type rocks 
in the geochemical diagrams, although three of them overlap into the field of Maine-type rocks, but still relatively close to the Rhine-type field. Overall, these three show rather low concentrations of LREE, as well as Nb (Figs. 17A, 18A), so it is not clear whether they resulted from a difference in petrogenetic process or from mobilization of multiple elements during amphibolite-facies metamorphism. The orientation of extensional structures accompanying Bravo Lake volcanism has not yet been documented; if it is possible to determine this from the deformed and metamorphosed remains, we predict that faults and fissures (dykes) should be of Rhine-type, formed at a high angle to the thrust fault fabrics.

Another occurrence, which we considered for inclusion in the example set, is the late Devonian-earliest Mississippian section in the Roberts Mountain Allochthon in Nevada. This is clearly recording (Burchfiel and Royden 1991) an accretionary complex-passive continental margin overthrusting event (Antler Orogeny), probably from an arc-continent collision with much slab roll-back, and there are mafic volcanic rocks in the deep continental rise and slope lower plate section of late Devonian age. However, modern analyses of these late Devonian volcanics are few (3 by Madrid 1987). We chose not to include this example in the selected set because of the paucity of adequate geochemical data, and also from the absence of clear evidence of the orientation of associated extensional strain. The geochemical data from the three samples of volcanics of late Devonian age (Madrid 1987) suggests this is a Rhine-type alkalic suite, from which we would again predict faults or dykes of the same age to be developed at high angles to the thrust transport direction. Clearly, there is an opportunity here to investigate fully and characterize these volcanics better, and perhaps even to test the hypothesis offered in this paper, as with the other possible examples identified by Bradley (2008).

\section{New Guinea}

Cloos et al. (2005) have documented in detail the Neogene arc-continental margin collision in New Guinea and the resulting slab breakoff event. Magmatism associated with the laterally propagating slab breakoff event is mostly confined to the orogen, with only a small area of volcanism just crossing the southern thrust boundary in the eastern (younger) part of the system. The New Guinea magmatism therefore is in contrast to most of the examples discussed in this paper, being largely not located in the foreland basin and, where it does slightly emerge into the northern edge of the basin, in occurring later than much of the sedimentary fill and the active thrust loading of that basin. Because of these differences, and the focus of this paper on magmatism located in and emplaced during the filling of collisional foreland basins, we chose not to include it among the examples. In general, the mafic members of the suite in Papua (Mackenzie 1976) have properties that mostly resemble (Schoonmaker et al. 2005) the Maine-type suites of this paper, consistent with the demonstration of Cloos et al. (2005) that they originated dominantly from decompression melting during the slab breakoff process. However, some occurrences of more alkaline types (e.g. the Porgera Intrusive
Complex, Richards et al. 1990), and others in western New Guinea (Housh and McMahon 2000) show that this was not the only source of these magmas and that a minority have Rhine-type compositions, probably derived from locally enriched lithosphere.

\section{Secular Variation?}

One curious feature of our selected example set is the skewed distribution in long-term geological history. The Rhine-type set contains four of Neogene-Recent, and one of Paleozoic age, whereas the Maine-type set consists of no modern, two Paleozoic, and three Proterozoic items. We think this might be significant, especially for the Maine-type, although the small overall number of items in our selection hardly permits a firm conclusion. However, the widespread occurrence of the Maine-type in extensive segments of the early Proterozoic orogens of Canada contrasts strongly with their definitive absence from extensive lengths of Phanerozoic orogens and, apart from the Maine Acadian, very minor volume magmatism in the Taconic example. Following Hofmann (1987) we think that it is plausible that a long-term secular change has reduced the likelihood of Maine-type magmatism in the foreland margins of collisional orogens. A possible cause might be reduction of upper mantle conductive heat transfer into continental lithosphere through time, and/or a longer average time interval from rifting to collision (Hoffman 1987) based on declining mantle heat generation rate and consequent slower average plate motion (e.g. Burke et al. 1976). Both of these would provide on average a thicker (and consequently stronger) lithosphere under passive continental margins at collision, less likely to rupture early in the process for younger collisional events. Alternatively, perhaps there was an unusual coincidence of circumstances for the early Proterozoic of the Canadian cratonic-margin orogens, if the magmatism was caused by one or more 'superplumes' (Ernst and Buchan 2004; Minifie 2010) but with magmatism localized by slabs ready to break off on margins near to or already involved in the collisional events.

\section{Mantle Plumes?}

Some authors have suggested mantle plumes are the cause of and occur under the area of Rhine Graben volcanism (Hoernle et al. 1994; Goes et al. 1999), and also for SE Turkey (Keskin 2003; Krienitz et al. 2009; Ekici et al. 2012). We think the traceand rare earth element compositional evidence shows clearly for all the Rhine-type examples that the primary source is sublithospheric and sub-asthenospheric. The magmatism is localized in areas of a typical scale of up to a few hundred kilometres across, like some active volcanic hotspots demonstrated to have deep mantle plume-sourced magmatism, from compositional ( ${ }^{3} \mathrm{He}$ anomaly) and/or seismic tomographic evidence (e.g. Hawaii). The Rhine Graben magmatism overlies a plumelike seismic anomaly in the upper mantle (Ritter et al. 2001), inferred by Goes et al. (1999) to extend to the lower mantle. We suggest that upper mantle convection is likely to be involved in generating these Rhine-type foreland magmatic occurrences, but it has not been demonstrated whether any of the others might also have a deep mantle plume connection. 
Table 2. Foreland magmatism examples, and New Guinea, ordered by time of interval of magmatism (vtime) relative to start of collision (continental crust entering under the accretionary toe), or subduction age (for petit-spots). Estimated on basis of stratigraphic relationship to foreland basin clastic rocks, and numerical ages where known, or estimated; for the Precambrian examples, estimated by comparison to the younger examples, presuming comparable convergence rates. Refer to Figure 1 for relative position in a foreland basin profile section.

\begin{tabular}{lcclc}
\hline \hline Example & R-type & M-type & Tectonic setting for time of volcanism & vtime M.y. \\
\hline $\begin{array}{l}\text { Rhine Graben } \\
\text { Cortlandt }\end{array}$ & $\mathrm{X}$ & & non-marine foreland basin and platform & 35 to 50 \\
Karacadağ & $\mathrm{X}$ & & $\begin{array}{l}\text { collisional belt (non-marine foreland basin) } \\
\text { collisional non-marine foreland basin }\end{array}$ & $\sim 15$ \\
New Guinea & & $\mathrm{X}$ & collisional thrust belt and orogen interior & 7 to 15 \\
Flaherty/Molson & & $\mathrm{X}$ & marine foreland basin over shelf strata & 75 \\
Piscataquis (Maine) & & $\mathrm{X}$ & marine foreland basin over shelf strata & $? \sim 5$ to 10 \\
Morel/Ghost & & $\mathrm{X}$ & marine foreland basin on or near shelf break & $\sim 5$ to 10 \\
Starks/Jonestown & & $\mathrm{X}$ & on continental shelf inside flexural bulge & $? \sim 0$ to 5 \\
Japan petit spots & $\mathrm{X}$ & & ocean floor outer trench slope to outside flexural bulge & $\sim-5$ to 0 \\
Penghu & $\mathrm{X}$ & & on continental shelf, well beyond flexural bulge & $(-8$ to 0$)$ \\
\hline
\end{tabular}

\section{Timing of Magmatism Relative to Start of Collision}

For the examples of foreland magmatism, if they are listed by order of the age of magmatism relative to the initiation of collision, or age at subduction of the volcanic rocks for the Japan petit spots (Table 2), the pattern emerges of the Maine-type being concentrated near this time, with the Rhine-type before or after. The concentration in time of the Maine-type may be because, if slab detachment occurs at all, it takes place soon after collision starts (see Cloos et al. 2005).

\section{CONCLUSIONS}

Contemporaneous magmatism in modern convergent or collisional foreland settings is readily recognized, but in ancient settings recognition relies on the presence of underlying passive margin sedimentation and overlying or contemporaneous deeper water sedimentary rocks, turbidites and flysch, and the association with collisional deformation. The several modern and ancient examples of foreland magmatism identified using those criteria fall strikingly into two distinct chemical groups defined by their trace element compositions: a more enriched alkaline group and a less enriched tholeiitic group. These two groups likely reflect two different processes that can occur in thrust forelands during arc or continental collision. The alkaline group is sourced from the sub-asthenospheric mantle and is inferred to result primarily from upwelling convection of plume-type geometry. The more tholeiitic group resulted from extension of the lower plate experiencing slab-pull forces and in some cases lithospheric detachment, with consequent melting of upwelling asthenospheric mantle. In either case, incorporation of melts from lithospheric mantle can occur, from intrusion or detachment, and in places (Maine) this can show evidence of previous modification by subduction processes. The geochemical results are quite sufficiently distinct to permit discrimination of such foreland magmatic rock suites from each other in ancient examples. However, they cannot be separated only by the geochemistry from magmatic products of other tectonic environments where similar compositions can be generated. While there may be in general lesser amounts of partial melting and magma volumes in the Rhine-type examples, the minor element geochemistry shows that the two types are not a result of differing degrees of partial melting of a single mantle source type.

For those foreland settings where coeval extensional structures reveal the extensional stress orientation during basin development, Maine-type magmatism is accompanied by normal faults parallel to the thrust front or trench. We think it is most implausible that the small amount of extension induced by lithospheric flexure of a few degrees or less, localized entirely in and widely distributed across the outer part of an antiformal bend, will lead to any surface magmatism. The examples of Maine-type foreland magmatism and the associated outer slope normal fault and dyke systems are evidence that they result from whole-lithosphere extension induced by slab pull. Rhine-type basin orientations are more variable, although several of our examples (Rhine Graben, Karacadağ, Cortlandt) have fissures or dykes and normal faults nearly perpendicular to the thrust front or trench, reflecting the orientation of the maximum compressive stress in the foreland crust imposed by the active plate boundary convergence. Oblique orientations could result either from oblique plate convergence (Japan petit spots), or from extension using older inherited fractures in the local crust (Penghu Islands?) and/or from stress fields modified by regional continental escape tectonics (Burke and Şengör 1986).

It is possible that there has been a long-term secular decrease in the occurrence of the Maine-type foreland magmatism since the early Proterozoic, and this aspect of foreland magmatism needs further investigation. 


\section{ACKNOWLEDGEMENTS}

We thank Ray Coish and an anonymous reviewer for their helpful comments on the manuscript, and donors to the University at Albany Foundation fund for Geological Sciences, which paid for some of the geochemical analyses of the Taconic and Acadian volcanic rocks used in this paper. Also, thanks to Camille Partin of the University of Saskatchewan for her suggestion that the Bravo Formation might be included in this study.

Dedicated to Andrew Hynes, whose field and lab research provided significant discoveries about, and still useful geochemical data on, both the Maine Acadian and the Belcher Island Proterozoic volcanic rocks included in this paper. We also wish to acknowledge General John Stark who, by hauling cannon to the top of the hill of pillow lava now known as Starks Knob, prevented in 1777 the escape back to Canada of Johnny Burgoyne and his defeated army, and by this role in causing their surrender near that place helped significantly to rid the sub-Canadian part of Laurentia of monarchy.

\section{REFERENCES}

Ammirati, J-B., Alvarado, P., Perarnau, M., Saez, M., and Monsalvo, G., 2013, Crustal structure of the central Precordillera of San Juan, Argentina $\left(31^{\circ} \mathrm{S}\right)$ using teleseismic receiver functions: Journal of South American Earth Sciences, v. 46, p. 100-109, http://dx.doi.org/10.1016/j.jsames.2013.05.007.

Angelier, J., Bergerat, F., Chu, Hao Tsu, Juang, Wen Shing, and Lu, Chia Yu, 1990, Paleostress analysis as a key to margin extension: The Penghu Islands, South China Sea: Tectonophysics, v. 183, p. 161-176, http://dx.doi.org/10.1016/ 0040-1951(90)90414-4.

Ashcroft, T.J., 2002, Field relations, structural geology, and geochemistry of the Jonestown volcanic field, Lebanon County, southeastern Pennsylvania: Unpublished Ph.D. thesis, State University of New York at Albany, Albany, NY, 111 p.

Baragar, W.R.A., 2007, Geology, Ottawa Islands, eastern Hudson Bay, Nunavut: Geological Survey of Canada Map 2113A.

Baragar, W.R.A., 2008, Geology, Smith Island and adjoining mainland, eastern Hudson Bay, Nunavut-Quebec: Geological Survey of Canada Map 2112A.

Bender, J.F., 1980, Petrogenesis of the Cortlandt Complex: Unpublished Ph.D. thesis, State University of New York at Stony Brook, Stony Brook, NY, 321 p.

Bender, J.F., Hanson, G.N., and Bence, A.E., 1984, Cortlandt Complex; differentiation and contamination in plutons of alkali basalt affinity: American Journal of Science, v. 284, p. 1-57, http://dx.doi.org/10.2475/ajs.284.1.1.

Berg, T.M., Edmunds, W.E., Geyer, A.R., Glover, A.D., Hoskins, D.M., MacLachlan, D.B., Root, S.I., Sevon, W.D., and Socolow, A.A., 1980, Geologic map of Pennsylvania, (1:250,000): Pennsylvania Topographical and Geological Survey, Harrisburg, Pennsylvania.

Bogaard, P.J.F., and Wörner, G., 2003, Petrogenesis of basanitic to tholeiitic volcanic rocks from the Miocene Volgelsberg, Central Germany: Journal of Petrology, v. 44, p. 569-602, http://dx.doi.org/10.1093/petrology/44.3.569.

Boucot, A.J., Field, M.T., Fletcher, R., Forbes, W.H., Naylor, R.S., and Pavlides, L., 1964, Reconnaissance bedrock geology of the Presque Isle quadrangle, Maine: Maine Geological Survey Quadrangle Mapping Series, no. 2, 123 p.

Bradley, D.C., 2008, Passive margins through earth history: Earth Science Reviews, v. 91, p. 1-26, http://dx.doi.org/10.1016/j.earscirev.2008.08.001.

Bradley, D.C., and Kidd, W.S.F., 1991, Flexural extension of the upper continental crust in collisional foredeeps: Geological Society of America Bulletin, v. 103, p. 1416-1438, http://dx.doi.org/10.1130/0016-7606(1991)103<1416:FEOTUC>2.3.CO;2.

Bradley, D.C., and Tucker, R., 2002, Emsian synorogenic paleogeography of the Maine Appalachians: The Journal of Geology, v. 110, p. 483-492, http://dx.doi.org/10.1086/340634.

Bradley, D.C., Tucker, R.D., Lux, D.R., Harris, A.G., and McGregor, D.C., 2000, Migration of the Acadian Orogen and foreland basin across the northern Appalachians of Maine and adjacent areas: United States Geological Survey Professional Paper 1624, $49 \mathrm{p}$.

Buchan, K.L., Ernst, R.E., Davis, W.J., Villeneuve, M., van Breemen, O., Bleeker, W., Hamilton, M.A., and Soderlund, U., 2009, Proterozoic Magmatic Events of the Slave Province, Wopmay Orogen and Environs: Geological Survey of Canada Open-File Report 5985, 23 p.

Burchfiel, B.C., and Royden, L.H., 1991, Antler orogeny: A Mediterranean-type orogeny: Geology, v. 19, p. 66-69, http://dx.doi.org/10.1130/00917613(1991)019<0066:AOAMTO>2.3.CO;2.

Burke, K., and Şengör, C., 1986, Tectonic escape in the evolution of the continental crust, in Barazangi, M., and Brown, L., eds., Reflection seismology: the continental crust: American Geophysical Union Geodynamics Series, v. 14, p. $41-$ 53, http://dx.doi.org/10.1029/GD014p0041.
Burke, K.C., Dewey, J.F., and Kidd, W.S.F., 1976, Dominance of horizontal movements, arcs and microcontinental collisions during the later permobile regime, in Windley, B.F., ed., The Early History of the Earth: John Wiley \& Sons, London, p. 113-130.

Camp, V.E., and Roobol, M.J., 1992, Upwelling asthenosphere beneath western Arabia and its regional implications: Journal of Geophysical Research, v. 97, p. 15255-15271, http://dx.doi.org/10.1029/92JB00943.

Cardozo, G.G.O., and Behrmann, J.H., 2006, Kinematic analysis of the Upper Rhine Graben boundary fault system: Journal of Structural Geology, v. 28, p. 1028 1039, http://dx.doi.org/10.1016/j.jsg.2006.03.010.

Chou Ying-Wei, and Yu Ho-Shing, 2002, Structural expressions of flexural extension in the arc-continent collisional foredeep of western Taiwan, in Byrne, T.B., and Liu, Char-Shine, eds., Geology and geophysics of an arc-continent collision, Taiwan: Geological Society of America Special Papers, v. 358, p. $1-$ 12, http://dx.doi.org/10.1130/0-8137-2358-2.1.

Chung Sun-Lin, Sun Shen-su, Tu Kan, Chen Cheng-Hong, and Lee Chi-yu, 1994, Late Cenozoic basaltic volcanism around the Taiwan Strait, SE China: Product of lithosphere-asthenosphere interaction during continental extension: $\mathrm{Chem}$ ical Geology, v. 112, p. 1-20, http://dx.doi.org/10.1016/0009-2541(94)901015.

Chung Sun-Lin, Jahn Bor-Ming, Chen Shu-Jen, Lee Typhoon, and Chen ChengHong, 1995, Miocene basalts in northwestern Taiwan: Evidence for EM-type mantle sources in the continental lithosphere: Geochimica et Cosmochimica Acta, v. 59, p. 549-555, http://dx.doi.org/10.1016/0016-7037(94)00360-X.

Cloos, M., Sapiie, B., Quarles van Ufford, A., Weiland, R.J., Warren, P.Q., and McMahon, T.P., 2005, Collisional delamination in New Guinea: The geotectonics of subducting slab breakoff: Geological Society of America Special Papers, v. 400, 51 p., http://dx.doi.org/ 10.1130/2005.2400.

Davies, J.H., and von Blanckenburg, F., 1995, Slab breakoff; A model of lithosphere detachment and its test in the magmatism and deformation of collisional orogens: Earth and Planetary Science Letters, v. 129, p. 85-102, http://dx.doi.org/10.1016/0012-821X(94)00237-S.

Davis, W.J., and Bleeker, W., 2007, New ages for Paleoproterozoic mafic intrusions in the western Slave Province and their potential relationship to tectonic events in the adjacent Wopmay Orogen (Abstract): Geological Association of Canada, Mineralogical Association of Canada Joint annual Meeting Abstracts, Waterloo, ON, v. 32, p. 20.

DeMets, C., Gordon, R.G., and Argus, D.F., 2010, Geologically current plate motions: Geophysical Journal International, v. 181, p. 1-80, http://dx.doi.org/10.1111/j.1365-246X.2009.04491.x.

Dèzes, P., Schmid, S.M., and Ziegler, P.A., 2004, Evolution of the European Cenozoic Rift System: interaction of the Alpine and Pyrenean orogens with their foreland lithosphere: Tectonophysics, v. 389, p. 1-33, http://dx.doi.org/ 10.1016/j.tecto.2004.06.011.

Domenick, M.A., and Basu, A.R., 1982, Age and origin of the Cortlandt Complex, New York: implications from Sm-Nd data: Contributions to Mineralogy and Petrology, v. 79, p. 290-294, http://dx.doi.org/10.1007/BF00371520.

Dostal, J., Wilson, R.A., and Keppie, J.D., 1989, Geochemistry of the Siluro-Devonian Tobique volcanic belt in the northern and central New Brunswick (Canada): tectonic implications: Canadian Journal of Earth Sciences, v. 26, p. 1282 1296, http://dx.doi.org/10.1139/e89-108.

Dunphy, J.M., Ludden, J.N., and Francis, D., 1995, Geochemistry of mafic magmas from the Ungava Orogen, Québec, Canada, and implications for mantle reservoir compositions at 2.0 Ga: Chemical Geology, v. 120, p. 361-380, http://dx.doi.org/10.1016/0009-2541(94)00146-Y.

Ekici, T., Macpherson, C.G., and Nazmi, O., 2012, Polybaric melting of a single mantle source during the Neogene Siverek phase of the Karacadağ Volcanic Complex, SE Turkey: Lithos, v. 146-147, p. 152-163, http://dx.doi.org/ 10.1016/j.lithos.2012.05.004.

Ekici, T., Macpherson, C.G., Otlu, N., and Fontignie, D., 2014, Foreland magmatism during the Arabia-Eurasian collision: Pliocene-Quaternary activity of the Karacadağ volcanic complex, SW Turkey: Journal of Petrology, v. 55, p. 1753 1777, http://dx.doi.org/10.1093/petrology/egu040.

Ernst, R.E., and Buchan, K.L., 2004, Igneous rock associations in Canada 3. Large Igneous Provinces (LIPs) in Canada and adjacent regions: 3 Ga to Present: Geoscience Canada, v. 31, p. 103-126.

Ershov, A.V., and Nikishin, A.M, 2004, Recent geodynamics of the Caucasus-Arabia-East Africa region: Geotectonics, v. 38, p. 123-136.

Eusden, J.D., Guzofski, C.A., Robinson, A.C., and Tucker, R.D., 2000, Timing of the Acadian Orogeny in northern New Hampshire: The Journal of Geology, v. 108, p. 219-232, http://dx.doi.org/10.1086/314396.

Fitton, J.G., Saunders, A.D., Norry, M.J., Hardarson, B.S., and Talyor, R.N., 1997, Thermal and chemical structure of the Iceland Plume: Earth and Planetary 
Science Letters, v. 153, p. 197-208, http://dx.doi.org/10.1016/S0012 821X(97)00170-2.

Fitzgerald, J.P., 1991, Geochemistry of the Spider Lake and West Branch Penobscot volcanic suites, northern Maine: Tectonic implication from a complex petrogenesis: Unpublished M.Sc. thesis, Boston College, Boston, MA, 254 p.

Frith, R.A., 1993, Precambrian geology of the Indin Lake map area, District of Mackenzie, Northwest Territories: Geological Survey of Canada Memoir 424, $63 \mathrm{p}$.

Goes, S., Spakman, W., and Bijward, H., 1999, A lower mantle source for central European volcanism: Science, v. 286, p. 1928-1931, http://dx.doi.org/ 10.1126/science.286.5446.1928.

Haase, K.M., Goldschmidt, B., and Garbe-Schönberg, C.-D., 2004, Petrogenesis of Tertiary continental intra-plate lavas from the Westerwald region, Germany: Journal of Petrology, v. 45, p. 883-905, http://dx.doi.org/10.1093/petrology/egg115

Heaman, L.M., Peck, D., and Toope, K., 2009, Timing and geochemistry of 1.88 Ga Molson igneous events, Manitoba: Insights into the formation of a cratonscale magmatic and metallogenic province: Precambrian Research, v. 172, p. 143-162, http://dx.doi.org/10.1016/j.precamres.2009.03.015.

Hildebrand, R.S., and Bowring, S.A., 1999, Crustal recycling by slab failure: Geology, v. 27, p. 11-14, http://dx.doi.org/10.1130/0091-7613(1999)027<0011: CRBSF> 2.3.CO;2.

Hildebrand, R.S., Bowring, S., and Hoffman, P.F., 2003, Evolution of arc-continent collision in Wopmay Orogen, northwestern Canada; upper plate extension to lower plate breakoff (Abstract): Geological Society of America Annual Meeting, Abstracts with Programs, v. 35, no. 6, p. 344

Hildebrand, R.S., Hoffman, P.F., and Bowring, S.A., 2010, The Calderian orogeny in Wopmay orogen $(1.9 \mathrm{Ga})$, northwestern Canadian Shield: Geological Society of America Bulletin, v. 122, p. 794-814, http://dx.doi.org/10.1130/B26521.1.

Hirano, N., 2011, Petit-spot volcanism: A new type of volcanic zone discovered near a trench: Geochemical Journal, v. 45, p. 157-167, http://dx.doi.org/10.2343/ geochemj.1.0111.

Hirano, N., Takahashi, E., Yamamoto, J., Abe, N., Ingle, S.P., Kaneoka, I., Hirata, T., Kimura, J-I., Ishii, T., Ogawa, Y., Machida, S., and Suyehiro, K., 2006, Volcanism in response to plate flexure: Science, v. 313, p. 1426-1428, http://dx.doi.org/10.1126/science.1128235.

Hoernle, K., Zhang, Yu-Shen, and Graham, D., 1994, Seismic and geochemical evidence for large-scale mantle upwelling beneath the eastern Atlantic and western and central Europe: Nature, v. 374, p. 34-39, http://dx.doi.org/ $10.1038 / 374034 \mathrm{a} 0$

Hoffman, P.F., 1987, Early Proterozoic foredeeps, foredeep magmatism, and Superior-type iron-formations of the Canadian Shield, in Kröner, A., ed., Proterozoic Lithospheric Evolution: American Geophysical Union Geodynamics Series, v. 17, p. 85-97, http://dx.doi.org/10.1029/GD017p0085.

Hoffman, P.F., 1988, United plates of America, the birth of a craton: early Proterozoic assembly and growth of Laurentia: Annual Reviews of Earth and Planetary Sciences, v. 16, p. 543-603, http://dx.doi.org/10.1146/ annurev.ea.16.050188.002551.

Homuth, B., Rümpker, G., Deckert, H., and Kracht, M., 2014, Seismicity of the northern Upper Rhine Graben - constraints on the present-day stress field from focal mechanisms: Tectonophysics, v. 632, p. 8-20, http://dx.doi.org/ 10.1016/j.tecto.2014.05.037.

Hon, R., Fitzgerald, J.P., Sergent, S.L., Schwartz, W.D., Dostal, J., and Keppie, J.D. 1992, Silurian-Early Devonian mafic volcanic rocks of the Piscataquis volcanic belt in northern Maine: Atlantic Geology, v. 28, p. 163-170, http://dx.doi.org/10.4138/1858

Housh, T., and McMahon, T.P., 2000, Ancient isotopic characteristics of Neogene potassic magmatism in western New Guinea (Irian Jaya, Indonesia): Lithos, v. 50, p. 217-239, http://dx.doi.org/10.1016/S0024-4937(99)00043-2.

Huang, Chi-Yue, Yuan, P.B., and Tsao, Shuh-Jung, 2006, Temporal and spatial records of active arc-continent collision in Taiwan: A synthesis: Geological Society of America Bulletin, v. 118, p. 274-288, http://dx.doi.org/10.1130/ B25527.1.

Hynes, A., and Francis, D.M., 1982, A transect of the early Proterozoic Cape Smith foldbelt, New Quebec: Tectonophysics, v. 88, p. 23-59, http://dx.doi.org/ 10.1016/0040-1951(82)90202-5.

Hynes, A., Francis, D., and Legault, F., 1994, Basalt petrochemistry as a probe of crustal thickness in the Hudson Bay Arc, Quebec: Earth and Planetary Science Letters, v. 127, p. 11-24, http://dx.doi.org/10.1016/0012-821X(94)90194-5.

Juang, W.S., and Chen, J.C., 1992, Geochronology and geochemistry of Penghu basalts, Taiwan Strait and their tectonic significance: Journal of Southeast Asian Earth Sciences, v. 7, p. 185-193, http://dx.doi.org/10.1016/07439547(92)90053-E.
Jung, C., Jung, S., Hoffer, E., and Berndt, J., 2006, Petrogenesis of Tertiary mafic alkaline magmas in the Hocheifel, Germany: Journal of Petrology, v. 47, p. 1637-1671, http://dx.doi.org/10.1093/petrology/egl023.

Jung, S., Pfänder, J.A., Brügmann, G., and Stracke, A., 2005, Sources of primitive alkaline volcanic rocks from the Central European Volcanic Province (Rhön, Germany) inferred from $\mathrm{Hf}, \mathrm{Os}$ and $\mathrm{Pb}$ isotopes: Contributions to Mineralogy and Petrology, v. 150, p. 54 559, http://dx.doi.org/10.1007/s00410-0050029-4.

Jung, S., Mezger, K., Hauff, F., Pack, A., and Hoernes, S., 2013, Petrogenesis of riftrelated tephrites, phonolites and trachytes (Central European Volcanic Province, Rhön, FRG): Constraints from $\mathrm{Sr}, \mathrm{Nd}, \mathrm{Pb}$ and $\mathrm{O}$ isotopes: Chemical Geology, v. 354, p. 203-215, http://dx.doi.org/10.1016/j.chemgeo, 2013.06.026.

Keppie, J.D., and Dostal, J., 1994, Late Silurian-Early Devonian transpressional rift origin of the Quebec Reentrant, northern Appalachians: Constraints from geochemistry of volcanic rocks: Tectonics, v. 13, p. 1183-1189, http://dx.doi.org/10.1029/94TC01504.

Keskin, M., 2003, Magma generation by slab steepening and breakoff beneath a subduction-accretion complex; an alternative model for collision-related volcanism in eastern Anatolia, Turkey: Geophysical Research Letters, v. 30, p. 9-1-94, http://dx.doi.org/10.1029/2003GL018019.

Keyser, M., Ritter, J.R.R., and Jordan, M., 2002, 3D shear-wave velocity structure of the Eifel plume, Germany: Earth and Planetary Science Letters, v. 203, p. 5982, http://dx.doi.org/10.1016/S0012-821X(02)00861-0.

Kidd, W.S.F., Plesch, A., and Vollmer, F.W., 1995, Lithofacies and structure of the Taconic flysch, mélange, and allochthon, in the New York Capital District, in Garver, J.I., and Smith, J.A., eds., Field Trip Guide for the $67^{\text {th }}$ Annual Meeting of the New York State Geological Association: Union College, Schenectady, NY, p. 57-80.

Kobayashi, K., Nakanishi, M., Tamaki, K., and Ogawa, Y., 1998, Outer slope faulting associated with the western Kurile and Japan trenches: Geophysical Journal International, v. 134, p. 356-372, http://dx.doi.org/10.1046/j.1365246x.1998.00569.x.

Krienitz, M.-S., Haase, K.M., Mezger, K., van den Bogaard, P., Thiemann, V., and Shaikh-Mashail, M.A., 2009, Tectonic events, continental intraplate volcanism, and mantle plume activity in northern Arabia: Constraints from geochemistry and $\mathrm{Ar}-\mathrm{Ar}$ dating of Syrian lavas: Geochemistry, Geophysics, Geosystems, v. 10, Q04008, http://dx.doi.org/10.1029/2008GC002254.

Landing, E., Pe-Piper, G., Kidd, W.S.F., and Azmy, K., 2003, Tectonic setting of outer trench slope volcanism: pillow basalt and limestone in the Taconian orogen of eastern New York: Canadian Journal of Earth Sciences, v. 40, p. 1773-1787, http://dx.doi.org/10.1139/e03-076.

Lash, G.G., 1986, Sedimentologic and geochemical evidence for Middle Ordovician near-trench volcanism in the central Appalachian orogen: The Journal of Geology, v. 94, p. 91-107, http://dx.doi.org/10.1086/629011.

Legault, F., Francis, D., Hynes, A., and Budkewitsch, P., 1994, Proterozoic continental volcanism in the Belcher Islands: implications for the evolution of the Circum Ungava fold belt: Canadian Journal of Earth Sciences, v. 31, p. 15361549, http://dx.doi.org/10.1139/e94-136.

Lustrino, M., and Carminati, E., 2007, Phantom plumes in Europe and the circumMediterranean region, in Foulger, G.R., and Jurdy, D.M., eds., Plates, Plumes, and Planetary Processes: Geological Society of America Special Papers, v. 430, p. 723-745, http://dx.doi.org/10.1130/2007.2430(33).

Mackenzie, D.E., 1976, Nature and origin of late Cainozoic volcanoes in western Papua New Guinea, in Johnson, R.W., ed., Volcanism in Australasia: Amsterdam, Elsevier, p. 221-238.

Madrid, R.J.J., 1987, Stratigraphy of the Roberts Mountains Allochthon in northcentral Nevada: Unpublished Ph.D. thesis, Stanford University, Stanford, CA, $453 \mathrm{p}$.

Meschede, M., 1986, A method of discriminating between different types of midocean ridge basalts and continental tholeiites with the $\mathrm{Nb}-\mathrm{Zr}-\mathrm{Y}$ diagram: Chemical Geology, v. 56, p. 207-218, http://dx.doi.org/10.1016/00092541(86)90004-5.

Minifie, M.J., 2010, The nature and origin of the $\sim 1880$ Ma circum-Superior large igneous province: Unpublished Ph.D. thesis, Cardiff University, Cardiff, UK, UMI Number U516947, 549 p.

Murphy, J.B., and Keppie, J.D., 2005, The Acadian Orogeny in the northern Appalachians: International Geology Review, v. 47, p. 663-687, http://dx.doi.org/10.2747/0020-6814.47.7.663.

Osberg, P.H., Hussey III, A.M., and Boone, G.M., 1985, Bedrock Geologic Map of Maine: Maine Geologic Survey, Augusta Maine, scale 1:500,000.

Partin, C.A., Bekker, A., Corrigan, D., Modeland, S., Francis, D., and Davis, D.W., 2014, Sedimentological and geochemical basin analysis of the Paleoprotero- 
zoic Penrhyn and Piling groups of Arctic Canada: Precambrian Research, v. 251, p. 80-101, http://dx.doi.org/10.1016/j.precamres.2014.06.010.

Pearce, J.A., 1982, Trace element characteristics of lavas from destructive plate boundaries, in Thorpe, R.S., ed., Andesites: Orogenic Andesites and Related Rocks, John Wiley and Sons, p. 525-548.

Pearce, J.A., 1996, A users guide to basalt discrimination diagrams, in Wyman, D.A., ed., Trace Element Geochemistry of Volcanic Rocks: Applications for Massive Sulphide Exploration, Geological Association of Canada, Short Course Notes, v. 12 , p. $79-114$.

Pearce, J.A., 2008, Geochemical fingerprinting of oceanic basalts with applications to ophiolite classification and the search for Archean oceanic crust: Lithos, v. 100, p. 14-48, http://dx.doi.org/10.1016/j.lithos.2007.06.016.

Pearce, J.A., 2014, Immobile element fingerprinting of ophiolites: Elements, v. 10, p. 101-108, http://dx.doi.org/10.2113/gselements.10.2.101.

Pearce, J.A., and Cann, J.R., 1973, Tectonic setting of basic volcanic rocks determined using trace element analyses: Earth and Planetary Science Letters, v. 19, p. 290-300, http://dx.doi.org/10.1016/0012-821X(73)90129-5.

Pearce, J.A., Bender, J.F., De Long, S.E., Kidd, W.S.F., Low, P.J., Güner, Y., Saroglu, F., Yilmaz, Y., Moorbath, S., and Mitchell, J.G., 1990, Genesis of collisional volcanism in eastern Anatolia, Turkey: Journal of Volcanology and Geothermal Research, v. 44, p. 189-229, http://dx.doi.org/10.1016/03770273(90)90018-B.

Rainbird, R.H., Davis, W.J., Pehrsson, S.J., Wodicka, N., Rayner, N., and Skulski, T., 2010, Early Paleoproterozoic supracrustal assemblages of the Rae domain, Nunavut, Canada: Intracratonic basin development during supercontinent break-up and assembly: Precambrian Research, v. 181, p. 167-186, http://dx.doi.org/10.1016/j.precamres.2010.06.005.

Ratcliffe, N.M., 1981, Cortlandt-Beemerville magmatic belt; A probable late Taconian alkalic cross trend in the central Appalachians: Geology, v. 9, p. 329-335, http://dx.doi.org/10.1130/0091-7613(1981)9<329:CMBAPL>2.0.CO;2.

Ratcliffe, N.M., Tucker, R.D., Aleinikoff, J.N., Amelin, Y., Merguerian, C., and Panish, P.T., 2012, U-Pb zircon and titanite ages of late- to post-tectonic intrusions of the Cortlandt-Beemerville magmatic belt, CT, NY, and NJ; relation to Iapetan closure in the Taconian Orogeny (Abstract): Abstracts with Programs of the Geological Society of American Annual Meeting, v. 44, no. 2, p. 73.

Richards, J.P., Chappell, B.W., and McCulloch, M.T., 1990, Intraplate-type magmatism in a continent-island-arc collision zone: Porgera intrusive complex, Papua New Guinea: Geology, v. 18, p. 958-961, http://dx.doi.org/10.1130/00917613(1990)018<0958:ITMIAC >2.3.CO;2.

Ricketts, B.D., Ware, M.J., and Donaldson, J.A., 1982, Volcaniclastic rocks and volcaniclastic facies in the Middle Precambrian (Aphebian) Belcher Group, Northwest Territories, Canada: Canadian Journal of Earth Sciences, v. 19, p. 1275-1294, http://dx.doi.org/10.1139/e82-109.

Ritter, J.R.R., Jordan, M., Christensen, U.R., and Achauer, U., 2001, A mantle plume below the Eifel volcanic fields, Germany: Earth and Planetary Science Letters, v. 186, p. 7-14, http://dx.doi.org/10.1016/S0012-821X(01)00226-6.

Schoonmaker, A., and Kidd, W.S.F., 2013, Tectonic significance of Cambro-Ordovician and Siluro-Devonian stratigraphy and magmatism in the Chesuncook Lake and Ripogenus Gorge area, north-central Maine, Field trip A-4, in Hanson, L.S., ed., Guidebook for field trips in Central Maine: New England Intercollegiate Geological Conference $105^{\text {th }}$ Annual meeting, Millinocket Lake, Maine, 11-13 October 2013, Salem State University, Salem, MA, p. 47-73.

Schoonmaker, A., Kidd, W.S.F., and Bradley, D.C., 2005, Foreland-forearc collisional granitoid and mafic magmatism caused by lower-plate lithospheric slab breakoff: The Acadian of Maine, and other orogens: Geology, v. 33, p. $961-$ 964, http://dx.doi.org/10.1130/G21832.1.

Schoonmaker, A., Kidd, W.S.F., Reusch, D.N., Dorais, M.J., Gregg, T., and Spencer, C., 2011, Stratigraphic context, geochemical, and isotopic properties of magmatism in the Siluro-Devonian inliers of northern Maine: implications for the Acadian Orogeny: American Journal of Science, v. 311, p. 528-572, http://dx.doi.org/10.2475/06.2011.03.

Sengör, A.M.C., and Kidd, W.S.F., 1979, Post-collisional tectonics of the TurkishIranian plateau and a comparison with Tibet: Tectonophysics, v. 55, p. $361-$ 376, http://dx.doi.org/10.1016/0040-1951(79)90184-7.

Şengör, A.M.C., Burke, K., and Dewey, J.F., 1978, Rifts at high angles to orogenic belts: tests for their origin and the Upper Rhine Graben as an example: American Journal of Science, v. 278, p. 24-40, http://dx.doi.org/10.2475/ ajs.278.1.24.

Şengör, A.C., Özeren, S., Genç, T., and Zor, E., 2003, East Anatolian high plateau as a mantle-supported, north-south shortened domal structure: Geophysical Research Letters, v. 30, 8045, http://dx.doi.org/10.1029/2003GL017858.

Shanmugan, G., and Lash, G.G., 1982, Analogous tectonic evolution of the Ordovician foredeeps, southern and central Appalachians: Geology, v. 10, p. 562-566,
http://dx.doi.org/10.1130/0091-7613(1982)10<562:ATEOTO>2.0.CO;2.

Shaw, C.S.J., and Woodland, A.B., 2012, The role of magma mixing in the petrogenesis of mafic alkaline lavas, Rockeskyllerkopf Volcanic Complex, West Eifel, Germany: Bulletin of Volcanology, v. 74, p. 359-376, http://dx.doi.org/ 10.1007/s00445-011-0532-6.

Shervais, J.W., 1982, Ti-V plots and the petrogenesis of modern and ophiolitic lavas: Earth and Planetary Science Letters, v. 59, p. 101-118, http://dx.doi.org/ 10.1016/0012-821X(82)90120-0.

Sibuet, J-C., Hsu, S-K., Le Pichon, X., Le Formal, J-P., Reed, D., Moore, G., and Liu, C-S., 2002, East Asia plate tectonics since 15 Ma: constraints from the Taiwan region: Tectonophysics, v. 344, p. 103-134, http://dx.doi.org/10.1016/S00401951(01)00202-5.

Smith, R.C., and Barnes, J.H., 1994, Geochemistry and geology of metabasalt in southeastern Pennsylvania and adjacent Maryland, in Faill, R.T., and Sevon., W.D., eds, Various aspects on Piedmont Geology in Lancaster and Chester counties, Pennsylvania: 59 $9^{\text {th }}$ Field Conference of Pennsylvania Geologists, p. $45-72$.

St-Onge, M.R., van Gool, J.A.M., Garde, A.A., and Scott, D.J., 2009, Correlation of Archean and Palaeoproterozoic units between northeastern Canada and western Greenland; constraining the pre-collisional upper plate accretionary history of the Trans-Hudson orogen, in Cawood, P.A., and Kröner, A., eds., Earth Accretionary Systems in Space and Time: Geological Society, London, Special Publications, v. 318, p. 193-235, http://dx.doi.org/10.1144/SP318.7.

Teng, L.S., and Lin, A.T., 2004, Cenozoic tectonics of the China continental margin: insights from Taiwan, in Malpas, J., Fletcher, C.J.N., Ali, J.R., and Aitchison, J.C., eds., Aspects of the tectonic evolution of China: Geological Society, London, Special Publications, v. 226, p. 313-332, http://dx.doi.org/10.1144/ gsl.sp.2004.226.01.17.

van Staal, C.R., Murphy, J.B., Fyffe, L.R., Karabinos, P., Whalen, J.B., and Keppie, J.D., 1998, Is the Acadian a Laramide-style orogeny? (Abstract): Geological Society of America Abstracts with Programs, $33^{\text {rd }}$ Annual Meeting, v. 30, p. 82.

van Staal, C.R., Whalen, J.B., Valverde-Vaquero, P., Zagorevski, A., and Rogers, N., 2009, Pre-Carboniferous, episodic accretion-related, orogenesis along the Laurentian margin of the northern Appalachians, in Murphy, J.B., Keppie, J.D., and Hynes, A.J., eds., Ancient Orogens and Modern Analogues: Geological Society, London, Special Publications, v. 327, p. 271-316, http://dx.doi.org/10.1144/ SP327.13.

Walcek, A.A., and Hoke, G.D., 2012, Surface uplift and erosion of the southernmost Argentine Precordillera: Geomorphology, v. 153-154, p. 156-168.

Wang, K-L., Chung, S-L., Lo, Y-M., Lo, C-H., Yang, H-J., Shinjo, R., Lee, T-Y., Wu, J-C., and Huang, S-T., 2012, Age and geochemical characteristics of Paleogene basalts drilled from western Taiwan: Records of initial rifting at the southeastern Eurasian continental margin: Lithos, v. 155, p. 426-441, http://dx.doi.org/10.1016/j.lithos.2012.10.002.

Winchester, J.A., and Floyd, P.A., 1977, Geochemical discrimination of different magma series and their differentiation products using immobile elements: Chemical Geology, v. 20, p. 325-343, http://dx.doi.org/10.1016/00092541(77)90057-2.

Wood, D.A., 1980, The application of a Th-Hf-Ta diagram to problems of tectonomagmatic classification and to establishing the nature of crustal contamination of basaltic lavas of the British Tertiary Volcanic Province: Earth and Planetary Science Letters, v. 50, p. 11-30, http://dx.doi.org/10.1016/0012821X(80)90116-8.

Yürür, M.T., and Chorowicz, J., 1998, Recent volcanism, tectonics, and plate kinematics near the junction of the African, Arabian, and Anatolian plates in the eastern Mediterranean: Journal of Volcanology and Geothermal Research, v. 85, p. 1-15, http://dx.doi.org/10.1016/S0377-0273(98)00046-8.

\section{Received February 2016 \\ Accepted as revised April 2016 \\ First published on the web August 2016}

